UNIVERSIDADE DE SÃO PAULO

FACULDADE DE ZOOTECNIA E ENGENHARIA DE ALIMENTOS

GABRIELLA VESPE DE MOURA

Desempenho, características de carcaça e qualidade de carne de bovinos Nelore e Rubia Gallega X Nelore confinados 
GABRIELLA VESPE DE MOURA

Desempenho, características de carcaça e qualidade de carne de bovinos Nelore e Rubia Gallega X Nelore confinados

Versão corrigida

Dissertação apresentada à Faculdade de Zootecnia e Engenharia de Alimentos da Universidade de São Paulo, como parte dos requisitos para a obtenção do título de Mestre em Ciências do programa de pós-graduação em Zootecnia.

Área de Concentração: Qualidade e Produtividade Animal

Orientador: Prof. Dra. Angélica Simone Cravo Pereira

Coorientador: Prof. Dra. Rosana Ruegger Pereira da Silva Corte 
Ficha catalográfica elaborada pelo Serviço de Biblioteca e Informação, FZEA/USP, com os dados fornecidos pelo(a) autor(a)

M929da, Gabriella

Desempenho, características de carcaça e qualidade de carne de bovinos Nelore e Rubia Gallega X Nelore confinados / Gabriella Moura ; orientadora Angélica Simone Cravo Pereira ; coorientadora Rosana Ruegger Pereira da Silva Corte. -- Pirassununga, 2020 .

$71 \mathrm{f}$.

Dissertação (Mestrado - Programa de Pós-Graduação em Zootecnia) -- Faculdade de Zootecnia e

Engenharia de Alimentos, Universidade de São Paulo.

1. Bos indicus. 2. Bos taurus. 3. dupla musculatura. 4. maciez. 5. fibra. I. Simone Cravo Pereira, Angélica, orient. II. Ruegger Pereira da Silva Corte, Rosana, coorient. III. Título. 


\section{CERTIFICADO}

Certificamos que a proposta intitulada "Desempenho, características de carcaça e qualidade de carne de bovinos Nelore e Rubia Gallega X Nelore confinados", protocolada sob o CEUA no 6849090518 (ID 001037), sob a responsabilidade de Angélica Simone Cravo Pereira e equipe; Gabriella Vespe de Moura - que envolve a produção, manutenção e/ou utilização de animais pertencentes ao filo Chordata, subfilo Vertebrata (exceto o homem), para fins de pesquisa científica ou ensino - está de acordo com os preceitos da Lei 11.794 de 8 de outubro de 2008, com o Decreto 6.899 de 15 de julho de 2009, bem como com as normas editadas pelo Conselho Nacional de Controle da Experimentação Animal (CONCEA), e foi aprovada pela Comissão de Ética no Uso de Animais da Faculdade de Zootecnia e Engenharia de Alimentos da Universidade de São Paulo - FZEA/USP (CEUA/FZEA) na reunião de $17 / 10 / 2018$.

We certify that the proposal "Performance, carcass traits and meat quality of feedlot Nellore and Galician Blond X Nelore cattle", utilizing 32 Bovines (32 males), protocol number CEUA 6849090518 (ID 001037), under the responsibility of Angélica Simone Cravo Pereira and team; Gabriella Vespe de Moura - which involves the production, maintenance and/or use of animals belonging to the phylum Chordata, subphylum Vertebrata (except human beings), for scientific research purposes or teaching - is in accordance with Law 11.794 of October 8, 2008, Decree 6899 of July 15, 2009, as well as with the rules issued by the National Council for Control of Animal Experimentation (CONCEA), and was approved by the Ethic Committee on Animal Use of the School of Animal Science and Food Engineering - (São Paulo University) (CEUA/FZEA) in the meeting of 10/17/2018.

Finalidade da Proposta: Pesquisa (Acadêmica)

Vigência da Proposta: de 08/2017 a 08/2019 Área: Zootecnia

Origem: Faculdade de Zootecnia e Engenharia de Alimentos (FZEA/USP)

Espécie: Bovinos sexo: Machos

Linhagem: Nelore e Rubia Gallega x Nelore

idade: 10 a 12 meses $\quad \mathrm{N}: 32$

Peso: $\quad 220$ a $300 \mathrm{~kg}$

Local do experimento: Os animais serão alojados no confinamento do Laboratório de Pesquisa em Gado de Corte, após o período experimental eles serão abatidos no abatedouro escola, ambos localizados no Campus Fernando Costa.

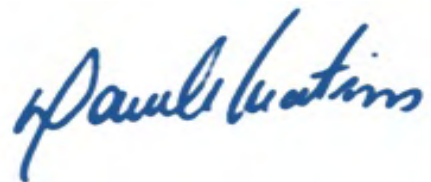

Profa. Dra. Daniele dos Santos Martins Coordenadora da Comissão de Ética no Uso de Animais Faculdade de Zootecnia e Engenharia de Alimentos da Universidade de São Paulo - FZEA/USP

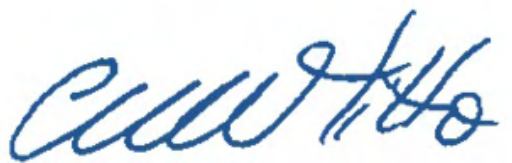

Profa. Dra. Cristiane Gonçalves Titto

Vice-Coordenadora da Comissão de Ética no Uso de Animais Faculdade de Zootecnia e Engenharia de Alimentos da Universidade de São Paulo - FZEA/USP 


\title{
Desempenho, características de carcaça e qualidade de carne de bovinos Nelore e Rubia Gallega X Nelore confinados
}

\author{
Dissertação apresentada à Faculdade de \\ Zootecnia e Engenharia de Alimentos da \\ Universidade de São Paulo, como parte dos \\ requisitos para a obtenção do título de Mestre \\ em Ciências
}

Área de Concentração: Qualidade e Produtividade Animal

Orientador: Prof. Dra. Angélica Simone Cravo Pereira

Coorientador: Prof. Dra. Rosana Ruegger Pereira da Silva Corte

Data de Aprovação:
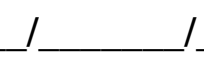

Banca examinadora:

Prof. Dr.:

Instituição: Julgamento:

Prof. Dr.:

Instituição: Julgamento:

Prof. Dr.:

Instituição: Julgamento:

Prof. Dr.:

Instituição: Julgamento: 
Aos meus pais, Rosária e Sérgio, e ao meu irmão, Giovanni, por acreditarem nos meus sonhos, por todo o apoio, amor, compreensão, incentivo e dedicação; e aos meus amigos que sempre estiveram ao meu lado, ajudando e vibrando pelas minhas conquistas. 


\section{AGRADECIMENTOS}

Aos meus pais, Rosária e Sérgio, a base de minha existência, pela educação que me proporcionaram e pela melhor orientação pessoal e profissional.

Ao meu irmão, Giovanni, e também o meu cunhado, Felipe, por todo apoio, incentivo e ajuda.

Aos demais familiares, avós, tios e primos que mesmo distante torceram por mim e acreditaram nos meus objetivos.

A minha segunda família em Pirassununga, a República Red bull, pelos melhores momentos compartilhados, por todo suporte, compreensão e conselhos. Sou imensamente grata por ter vocês na minha vida, fazem meus dias mais felizes. Independente de onde eu esteja vou me lembrar dos verdadeiros e eternos amigos como vocês.

A minha orientadora, Professora Angélica Simone Cravo Pereira, pela orientação, confiança, amizade e ensinamentos compartilhados durante o mestrado.

A minha coorientadora, Rosana Ruegger P. da Silva Corte, pela orientação, dedicação e contribuição na fase experimental e descritiva deste trabalho.

Aos colegas de trabalho do Laboratório de Ciência da Carne (LCC) e Laboratório de Pesquisa em Gado de Corte (LPGC) por compartilhar diversos momentos de aprendizado e descontração, contribuindo para minha formação profissional e pessoal de cada dia.

Aos estagiários que auxiliaram principalmente na parte prática do projeto, meus sinceros agradecimentos. Vocês foram essenciais para que a fase de confinamento ocorresse da melhor forma possível. Compartilhamos diversos momentos agradáveis que nunca irei me esquecer. Torço muito pelo sucesso de vocês!

A minha companheira de experimento e amiga, Adrielle Matias Ferrinho, obrigada pela ajuda e amizade.

A minha amiga e "irmã", Lidiane Grigoletto, pela amizade e apoio em todos os momentos.

Aos Prof. Dr. Saulo da Luz e Silva (Laboratório de Avaliação Animal e Qualidade de Carne) e Daniele dos Santos Martins (Laboratório de Morfofisiologia Molecular e Desenvolvimento) por fornecer os respectivos laboratórios para análises de qualidade de carne.

Ao Prof. Dr. Fernando Baldi pelo auxílio na análise estatística.

A todos os professores os quais tive oportunidade de ter aula e discutir assuntos 
pertinentes da nossa área, agradeço pelos valiosos ensinamentos.

Aos funcionários e ex-funcionários do LPGC. Em especial ao Schmidt por toda a dedicação e atenção nos cuidados diários dos animais e por sempre estar disposto a ajudar e ensinar sem medir esforços.

Aos funcionários da fábrica de ração e do abatedouro escola por estarem sempre dispostos a ajudar e auxiliar nas atividades.

As secretárias, Alessandra, Fabia, Maria Cecília e Érica, e também a técnica Simi pela paciência e serviços.

Aos meus colegas pertencentes ao Laboratório de Avaliação Animal e Qualidade de Carne (LAAQC), por toda ajuda e apoio nas análises.

À Faculdade de Zootecnia e Engenharia de Alimentos (FZEA/USP) pela oportunidade de realização do curso de graduação e mestrado.

À Coordenação de Aperfeiçoamento de Pessoal de Nível Superior (CAPES) pela concessão da bolsa de estudos.

À Fundação de Amparo à Pesquisa do Estado de São Paulo (FAPESP; processo n ${ }^{\circ}$ 2012/50788-0).

A todos que de forma direta ou indireta contribuíram para a realização desse trabalho. 
"É exatamente disso que a vida é feita: de momentos! Momentos os quais temos que passar, sendo bons ou não, para o nosso próprio aprendizado, por algum motivo. Nunca esquecendo o mais importante: nada na vida é POR ACASO."

Chico Xavier

"Todos os nossos sonhos podem se tornar realidade, se tivermos a coragem de persegui-los."

Walt Disney 


\section{RESUMO}

MOURA, G. V. Desempenho, características de carcaça e qualidade de carne de bovinos Nelore e Rubia Gallega X Nelore confinados. 2020. 71 f. Dissertação (Mestrado). Faculdade de Zootecnia e Engenharia de Alimentos, Universidade de São Paulo, Pirassununga, 2020.

Objetivou-se neste estudo avaliar e comparar a taxa de crescimento, desempenho, características de carcaça e qualidade da carne de bovinos Nelore e cruzados Rubia Gallega e Nelore, terminados em confinamento. Foram utilizados 16 Nelore $(\mathrm{N})$ e 16 Rubia Gallega $\mathrm{x}$ Nelore (RGN), machos não castrados, com peso médio inicial de $280 \mathrm{~kg} \pm 15 \mathrm{~kg}$ e $11 \pm 2$ meses de idade, confinados por 120 dias e a cada 28 dias form realizadas pesagem e ultrassonografia, considerando um delineamento inteiramente casualizado. Os bovinos receberam duas dietas, terminação 1 - 70\% de concentrado, e terminação 2 - 85\% de concentrado. Foi avaliada a ingestão de matéria seca (IMS), peso vivo médio inicial e final (PI, PF), ganho de peso médio diário (GMD) e eficiência alimentar (EA). No abate foi determinado o peso de carcaça quente (PCQ) e o rendimento de carcaça (RC), e foram colhidas amostras do músculo Longissimus thoracis ( $L T H)$ para determinação do tipo, número e diâmetro de fibras musculares. Durante a desossa, foram avaliados o pH, área do olho de lombo (AOL), espessura de gordura subcutânea (EGS) e marmorização (MARB), e coletadas amostras para a análise de perdas por cocção (PPC), maciez objetiva (FC), maciez subjetiva (sensorial), cor, lipídios totais (LT) e colágeno no músculo LTH. A maciez objetiva, PPC e cor foi realizada em amostras maturadas por zero, 7,14 e 21 dias a $2^{\circ} \mathrm{C}$. Para a análise sensorial da carne, os bifes foram maturados por zero e 14 dias a $2^{\circ} \mathrm{C}$. Os resultados foram submetidos à análise de variância (ANOVA), utilizando o proc MIXED do SAS versão 9.3, considerando $\mathrm{P}<0,05$. Bovinos RGN apresentaram melhor desempenho e características de carcaça superiores ao N (P < 0,05), obtendo $500 \mathrm{~g}$ de GMD a mais por dia e, RC 1,3\% maior que os animais N. Observou-se interação linear para as características de espessura de gordura da carcaça, avaliadas por ultrassom, com a evolução do tempo de confinamento $(\mathrm{P}<0,05)$, sugerindo que a deposição de gordura foi mais rápida e maior em bovinos N. Houve diferença entre os grupos genéticos para FC, PPC, cor ( $\mathrm{L}^{*}, \mathrm{a}^{*} \mathrm{e}$ $\left.\mathrm{b}^{*}\right)$ e LT $(\mathrm{P}<0,05)$, indicando maior maciez e menor quantidade de gordura na carne de animais cruzados. No entanto, não foram encontradas alterações na quantidade de colágeno e no número e diâmetro das fibras musculares $(\mathrm{P}>0,05)$. Também não houve diferença sensorial na carne dos diferentes grupos, havendo apenas para o tempo de maturação $(\mathrm{P}<0,0001)$. Assim, de modo geral, o uso do cruzamento industrial potencializa a produtividade, proporcionando maior taxa de crescimento muscular, no entanto, não gera grandes influências na qualidade da carne, mas pode ser uma alternativa ao consumidor que busca alimentos com menor conteúdo de gordura.

Palavras-chave: Bos indicus, Bos taurus, dupla musculatura, maciez, colágeno, fibra. 


\begin{abstract}
MOURA, G. V. Performance, carcass traits and meat quality of feedlot Nelore and Rubia Gallega x Nelore cattle. 2020. 71 f. Dissertation (Masters). Faculdade de Zootecnia e Engenharia de Alimentos, Universidade de São Paulo, Pirassununga, 2020.
\end{abstract}

This work aimed to evaluate and compare performance, carcass traits and meat quality of Nelore and Rubia Gallega x Nelore cattle, finished in feedlot. Sixteen Nelore (N) and 16 crossbred Rubia Gallega x Nelore (RGN), non-castrated males, with an average age of 11 months and $280 \mathrm{~kg} \pm 15 \mathrm{~kg}$ of initial live weight were used, confined for 120 days and weighing and ultrasonography were performed every 28 days, considering a completely randomized design. The cattle received two diets, according to the finishing phase (finishing $1-70 \%$ of concentrate; finishing 2 - 85\% of concentrate). Dry matter intake (DMI, kg), initial weight and final weight (IW, FW, kg), average daily gain (ADG, $\mathrm{kg}$ ) and feed efficiency (FE) it were evaluated throughout the trial period. Hot carcass weight $(\mathrm{HCW})$ and carcass dressing percentage (CD) were discerned at slaughter, and samples of the Longissimus thoracis (LTH) muscle were collected for determination of the type, number and diameter of muscle fibers. After 24 hours, in deboning, $\mathrm{pH}$, rib eye area (REA), fat thickness (FT) and marbing (MARB) were evaluated in $L T H$ muscle, between the 12th and 13th rib. For analysis cooking loss (CL), shear force (SF), Sensory analysis (SA), color, total lipids (TL) and collagen samples of the same muscle were collected. Samples for SF, CL and color were aged for zero, 7, 14 and 21 days. For SA samples were aged for zero and 14 days at $2{ }^{\circ} \mathrm{C}$. The results were submitted to analysis of variance (ANOVA), using the SAS version 9.3 MIXED proc, considering $\mathrm{P}<0,05$. RGN cattle had better performance and superiors carcass traits $(\mathrm{P}<0,05)$ when compared to $\mathrm{N}$, getting higher ADG $500 \mathrm{~g}$ and, 1,3\% CD more to $\mathrm{N}$ animals. There was linear interaction for fat, evaluated by ultrasound, with the evolution of the feedlot time $(\mathrm{P}<0.05)$, suggesting that the fat deposition was faster and higher in N. For SF, CL, color $\left(\mathrm{L}^{*}, \mathrm{a}^{*} \mathrm{e} \mathrm{b}^{*}\right)$ and TL, there were difference between the genetic groups $(\mathrm{P}<0,05)$, indicating more tender and less fat meat of crossbred animals. However, there were no difference in amount of collagen and in the number and diameter of muscle fibers $(\mathrm{P}>0,05)$. There was also no difference in AS between genetic groups, there being only for the aging time, $(\mathrm{P}<0,0001)$. In general, the use of crossing enhances productivity, providing a higher rate of muscle growth, however, it does not affect on meat quality, but it can be an alternative for consumers looking for meat with less fat.

Keywords: Bos indicus, Bos taurus, double muscle, tenderness, collagen, fiber. 


\section{SUMÁRIO}

\section{CAPÍTULO 1}

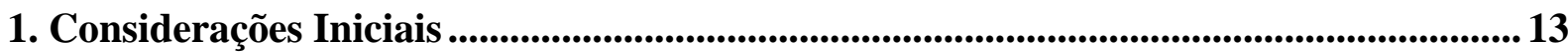

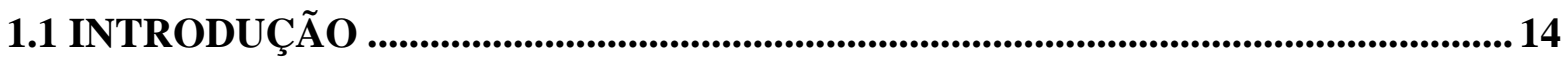

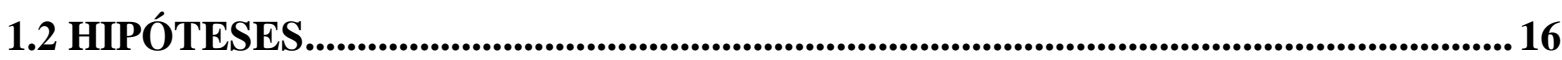

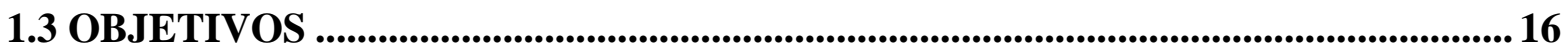

1.3.1 Objetivos gerais .................................................................................................................. 16

1.3.2 Objetivos específicos.................................................................................................. 16

1.4 REVISÃO DE LITERATURA..................................................................................... 17

1.4.1 Bos taurus continental............................................................................................... 17

1.4.2 Características de Crescimento Animal....................................................................... 21

1.4.3 Qualidade da carne .................................................................................................. 23

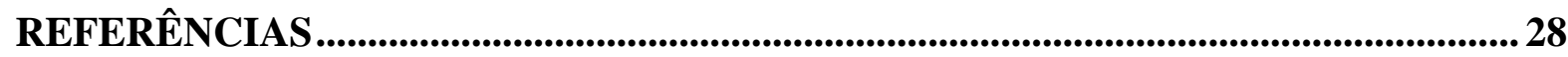

\section{CAPÍTULO 2}

2. Desempenho, características de carcaça e qualidade de carne de bovinos Nelore e cruzados Rubia Gallega X Nelore ..........................................................................................34

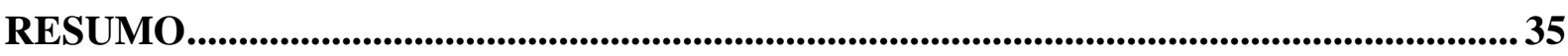

2.1 INTRODUÇÃ

2.2 MATERIAL E MÉTODOS .................................................................................37

2.2.1Local de execução..................................................................................................................37

2.2.2Animais, dietas e instalações .........................................................................................38

2.2.3Ultrassom ..............................................................................................................................39

2.2.4Abate, desossa e coleta de amostras .............................................................................. 40

2.2.5Rendimento de carcaça quente ........................................................................................ 40

2.2.6pH e temperatura.................................................................................................... 41

2.2.7Área de olho de lombo e espessura de gordura subcutânea....................................... 41

2.2.8 Índice de Marmorização.................................................................................................. 41

2.2.9Cor.......................................................................................................................41

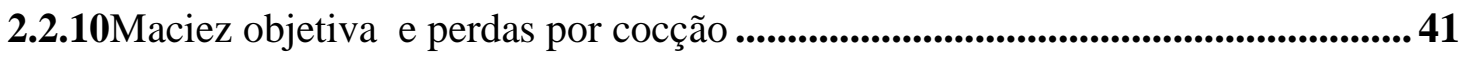

2.2.11Determinação de lipídios totais................................................................................ 42

2.2.12Determinação histológica do número e tipo de fibras musculares ........................ 42

2.2.13Quantificação de colágeno total e solúvel .................................................................. 43 
2.2.14Análise sensorial da carne in natura ......................................................................43

2.2.15Delineamento experimental e análise estatística .................................................43

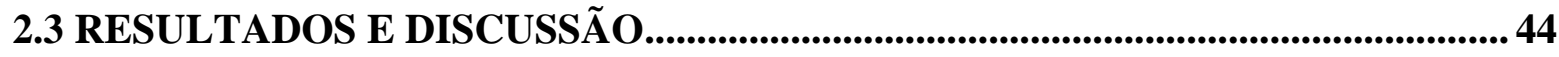

2.3.1 Características de desempenho............................................................................................. 44

2.3.2 Ultrassom e Características de carcaça.............................................................................. 46

2.3.3 Características de qualidade da carne........................................................................551

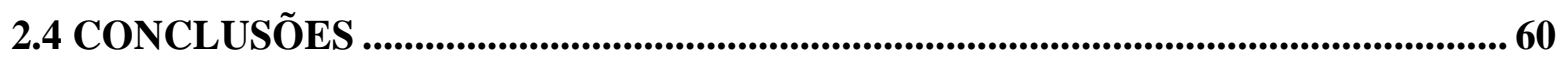

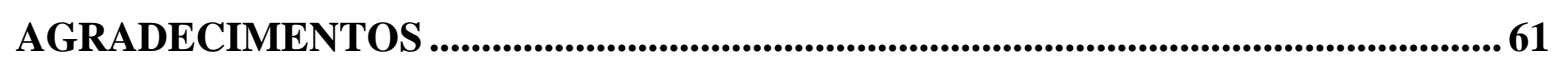

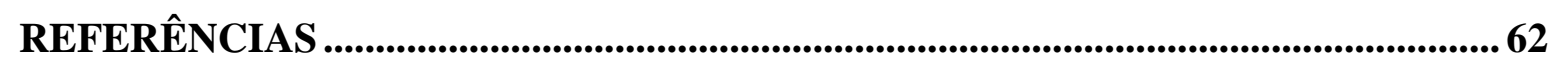

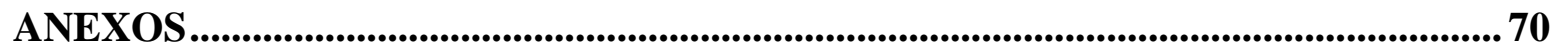




\section{CAPÍTULO 1}

Considerações Iniciais 


\subsection{INTRODUÇÃO}

A pecuária de corte é destaque no agronegócio brasileiro e de grande importância para a economia do país. Em 2018, o rebanho bovino brasileiro era de aproximadamente 232 milhões de cabeças de gado e produziu 9,9 milhões de toneladas equivalente carcaça (TEC) (USDA, 2019). Também, o Brasil foi considerado o maior exportador de carne bovina in natura do mundo, com volume aproximado de dois milhões de toneladas de carne em 2018 (USDA, 2019). No entanto, é possível observar que ainda são necessários maiores avanços tecnológicos, e a implantação de estratégias para a conquista e consolidação de novos mercados.

Atualmente, a maior parte do rebanho brasileiro é formado por raças zebuínas, principalmente Nelore $(\mathrm{N})$, que representam importante participação na produção do rebanho nacional. A representatividade do Nelore no sistema de produção de carne no país é decorrente há uma série de fatores, tais como: baixo custo de produção, extensão territorial privilegiada, existência de genótipos adaptados ao clima tropical, resistência a parasitas, eficiência na conversão de gramíneas tropicais, longevidade e fertilidade (KOURY FILHO, 2005).

Entretanto, os índices de produtividade do rebanho brasileiro são baixos, o que comprova a necessidade do uso de tecnologias apropriadas para o País (PEREIRA, 2000). E, ainda, são necessários avanços tecnológicos para melhorar a qualidade do produto final, bem como, a implantação de estratégias para conquistar e consolidar novos mercados. De acordo com a literatura, o uso de cruzamentos bem delineados pode melhorar os índices produtivos do rebanho brasileiro (EUCLIDES FILHO \& FIGUEIREDO, 2003).

Em consonância, a pecuária de corte vem se adaptando para diminuir os custos de produção e aumentar a rentabilidade. Além disso, a demanda por produtos de origem animal de boa qualidade e saudáveis para o consumo humano tem aumentado nos últimos anos. Dentre os atributos que se destacam, a maciez é um dos mais importantes para definir qualidade da carne e garantir aceitação e satisfação dos consumidores (KOOHMARAIE et al., 2002).

Nesse contexto, o melhoramento genético pode ser utilizado como ferramenta estratégica para aumentar os índices de produção e a qualidade da carne (WEBER et al., 2009). De acordo com Cruz et al. (2009), estratégias de intensificação da produção de carne, com utilização de grupos geneticamente melhorados e com redução da idade de abate dos animais, contribuem para elevar a taxa de desfrute da pecuária de corte brasileira.

Desse modo, são crescentes os estudos e o interesse dos produtores em desenvolver e aplicar estratégias para melhorar o rendimento animal juntamente com a qualidade das carcaças produzidas. Devido a maior exigência dos consumidores por produtos de qualidade e que 
satisfaçam suas necessidades quanto à segurança higiênico-sanitária, valor nutritivo e, principalmente, às características de qualidade da carne (SARCINELLI et al., 2007).

A ampla variação encontrada na qualidade da carne bovina se refere principalmente à maciez (BUAINAIN e BATALHA, 2007). Esse aspecto pode ser justificado pela grande fração zebuína encontrada na base genética do rebanho brasileiro (LAGE, 2012). Em geral, raças zebuínas apresentam carne menos macia quando comparadas com raças taurinas (PEREIRA, 2015).

A maciez é um atributo que faz com que o consumidor adquira carne e se disponha a pagar mais por ela (KOOHMARAIE et al., 2002). Porém, garantir a maciez da carne não é simples, o que faz os pesquisadores manterem o foco nessa característica. Assim, já foram estabelecidas importantes questões relacionadas às diferenças de maciez entre subespécies (KOOHMARAIE et al., 2006), sendo um exemplo a maior atividade inibitória da calpastatina sobre as calpaínas, com consequente redução do amaciamento, em animais Bos indicus quando comparados aos animais Bos taurus (WHEELER et al., 1990; PRINGLE et al., 1997; 1999).

Uma das estratégias para obter um produto superior é a utilização do cruzamento industrial (CI), realizado entre duas raças com características complementares. O cruzamento entre raças europeias (Bos taurus) com uma raça adaptada ao clima tropical (Bos indicus), como a Nelore, a qual possibilita a geração de animais com melhores aspectos produtivos (ganho de peso, musculosidade, peso de carcaça, precocidade), e também aspectos qualitativos da carcaça e da carne, como melhor conformação e maciez, o que agrega valor aos cortes comerciais.

Nesse sentido, a raça Rubia Gallega (Bos taurus) pode ser uma alternativa de cruzamento com animais da raça Nelore, com o propósito de melhorar as características quantitativas e qualitativas da carcaça, intensificando assim a produção e qualidade da carne (ALBERTí et al., 2005).

A raça Rubia Gallega é uma das mais importantes produzidas na Espanha, classificada como alta produtora de carne, com maturidade tardia, carcaças altamente musculosas, elevada taxa de crescimento e baixo conteúdo de tecido adiposo. Destacando-se também por sua longevidade e rusticidade, podendo se adaptar em ambientes diversos (ALBERTÍ et al., 2005).

Animais Rubia Gallega podem apresentar mutações no gene da miostatina (MSTN), a mutação resulta na inativação da proteína miostatina e, consequentemente, aumento da massa muscular, proporcionando o fenótipo musculatura dupla (DM). Isso resulta em carcaças com elevado rendimento de cortes comerciais, dispondo de maiores quantidades de peças com quantidade superior e composição favorável de carne (XAVIER, 2014). 
Estudos visando particularmente o impacto do cruzamento industrial sobre o desempenho animal e as características qualitativas da carcaça e da carne são fundamentais na atualidade. Tais estudos podem influenciar diretamente na lucratividade do país, por proporcionarem uma maior participação do Brasil em nichos de mercados mais exigentes em relação à produtividade e qualidade da carne. No entanto, apesar do cruzamento entre as raças Nelore e Rubia Gallega ser crescente no Brasil, ainda há insuficiência de dados na literatura para caracterização do fenótipo das progênies F1, resultantes do cruzamento entre as raças Nelore e Rubia Gallega. As diferenças no desempenho e qualidade da carne e da carcaça entre os animais Nelore e os F1 Nelore x Rubia Gallega (RGN) podem ser de origem intrínseca da raça, podendo ser explicadas, por exemplo por fatores genéticos. Assim, é fundamental entender os fatores envolvidos nas diferenças fenotípicas desses grupos genéticos.

Diante disso, pretende-se discutir os efeitos no desempenho, nas características de carcaça e qualidade de carne de bovinos Nelore e F1 Rubia Gallega x Nelore confinados.

\subsection{HIPÓTESE}

Animais cruzados Rubia Gallega e Nelore apresentam melhor desempenho, características de carcaça e qualidade de carne, quando comparados aos bovinos Nelore.

\subsection{OBJETIVOS}

\subsubsection{Objetivos gerais}

Avaliar e comparar o desempenho, características de carcaça e qualidade de carne de bovinos Nelore e cruzados Rubia Gallega e Nelore, terminados em confinamento.

\subsubsection{Objetivos específicos}

- Comparar o desempenho animal entre Nelore e cruzados Rubia Gallega x Nelore.

- Caracterizar a qualidade da carne dos animais.

- Quantificar a proporção de colágeno solúvel entre os grupos genéticos avaliados.

- Avaliar as características qualitativas da carne.

- Determinar a quantidade de colágeno e contagem do número de fibras musculares. 


\subsection{REVISÃO DE LITERATURA}

\subsubsection{Bos taurus continental}

As raças bovinas de interesse para produção de carne no Brasil podem ser classificadas como raças europeias da subespécie Bos taurus e raças indianas da subespécie Bos indicus. As raças europeias podem ser divididas em: raças europeias adaptadas ao clima tropical, como Caracu; raças europeias britânicas, como a Angus e Hereford; e raças europeias continentais, como Charolês, Limousin, Piemontês e Rubia Gallega (BRADLEY et al., 1998).

As raças continentais têm maiores taxa de crescimento, peso de abate e área de olho de lombo, indicando maior quantidade de carne na carcaça, porém são mais tardias para deposição de gordura do que as raças turinas britânicas (MORALES et al., 2002). Essas características aumentam o interesse em produzir animais utilizando o CI entre raças europeias e raças zebuínas, visando melhorias da qualidade do produto final.

Entretanto, a seleção do grupo genético a ser utilizado no CI depende de nichos de mercados específicos e tem sido amplamente estudada, como uma das ferramentas de melhoria na qualidade da carne, pois apresenta relação direta com o grau de acabamento da carcaça, taxa de crescimento, escore de marmorização, teor de solubilidade do colágeno e maciez da carne (CATTELAM et al., 2009; METZ et al., 2009a).

Dentre as raças citadas, a Rubia Gallega $(\mathrm{RG})$ é a mais importante entre as raças taurinas continentais na Espanha (ACRUGA, 2018) e vem sendo explorada no cruzamento industrial com animais zebuínos no Brasil, para nichos de mercados que visam maior proporção de carne na carcaça e menos gordura.

A raça $R G$ é uma das mais importantes produzidas na Espanha, classificada como alta produtora de carne, com maturidade tardia, apresenta carcaças altamente musculosas, com elevada taxa de crescimento e baixo conteúdo de tecido adiposo, destacando-se também por sua longevidade e rusticidade e, pode adaptar-se em ambientes diversos (ALBERTí et al., 2005). Essa raça originou-se do cruzamento de animais da raça de Gael, procedentes da zona céltica francesa, com animais existentes na Galícia (GMG, 2009a).

No Brasil, a introdução da raça RG ocorreu no ano 2000, quando houve a primeira experiência com inseminação artificial de matrizes Nelore com sêmen de RG. Após análise comparativa de amostras de carne entre animais brasileiros e animais cruzados RGN, foi verificado acréscimo de $38 \%$ na produção de carne nobre (file mignon e picanha) e de $37 \%$ na carne de melhor valor agregado (SANCHEZ et al., 2005a). Em 2003, ocorreu o abate de animais 
com 13 meses de idade, quando foi encontrada média geral de rendimento de carcaça de 60,6\% (GMG, 2009b).

Os resultados acima citados são consequência do alto potencial genético dos animais RG por produzirem elevado rendimento de carcaça e de cortes comerciais da carne, bem como, maior rendimento de cortes nobres da carne (OLIETE et al., 2006). Além disso, tem sido demonstrado que o cruzamento entre raças de clima temperado, como a Rubia Gallega, com as adaptadas ao clima tropical, gera animais mais produtivos e resistentes, podendo ainda explorar os efeitos da heterose, que podem estar relacionados não só nos aspectos produtivos, como ganho de peso, musculosidade, peso de carcaça, precocidade, mas também nos aspectos qualitativos da carcaça, como melhor acabamento, conformação e maciez (HAMMOUND et al., 1998).

Ademais, a raça RG pode apresentar fenótipo de dupla musculatura (DM), decorrente de mutações no gene da miostatina, que é uma proteína reguladora da miogênese, podendo provocar alterações na multiplicação celular (LEE et al., 2009). A DM ou hipertrofia muscular é uma condição hereditária em algumas raças bovinas, sendo Belgian Blue e Piemontês as raças mais estudadas que apresentam esse fenótipo, além de outras como a Asturiana de los Valles, Maine Anjou, Charolês, Limousin, Parthenaise e Rubia Gallega (HANSET, 1982; ARTHUR, 1995).

O aumento da musculatura em indivíduos DM ocorre devido ao aumento do número de fibras musculares e ao acréscimo individual dessas fibras (hiperplasia e hipertrofia, respectivamente), quando comparado ao bovino que não possui DM (ARTHUR, 1995; GAGNIERE et al., 1997).

Durante os primeiros dois terços da gestação, fase de maior multiplicação celular, o número de fibras é maior em feto que possui característica DM (ARTHUR, 1995; GAGNIERE et al., 1997). Ao nascimento, bezerros DM têm cerca do dobro do número de fibras musculares brancas (WEST, 1974). Logo, bovinos DM têm maior proporção de fibras brancas, além de menor quantidade de mioglobina dos músculos e menor quantidade de colágeno, quando comparado aos animais normais (UYTTERHAEGEN et al., 1994; BOCCARD, 1982).

Tais atributos, maior número e diâmetro de fibras musculares, resultam em carne relativamente mais macia de animais DM do que a de bovinos que não detém essa característica (BOCCARD, 1982; BAILEY et al., 1982).

Especificamente, o fenômeno da DM é decorrente de mutações em um gene recessivo denominado GDF8 (Growth Differentiation Factor 8) conhecido também como miostatina 
(MSTN; HAN, FORREST \& HICKFORD, 2013). A miostatina, proteína reguladora da miogênese provoca alteração na multiplicação celular no caso de mutações genéticas e sua função primária é atuar como um regulador negativo da miogênese. (MATSAKAS \& PATEL, 2009, LEE et al., 2009).

Em estudos envolvendo análises moleculares, McPherron e Lee (1997) testaram ratos e demonstraram que com o bloqueio da atividade do gene GDF-8 ocorre um aumento significativo na massa muscular dos animais, tendo esses a quantidade de gordura reduzida. Esses mesmos autores compararam as sequências gênicas da miostatina em dez espécies diferentes, confirmando que a hipertrofia muscular é causada pela perda da função da proteína miostatina.

O fenótipo de DM, característico da miogênese, é um passo fisiológico do crescimento animal, devido às modificações na formação do tecido muscular, o que diferencia a raça $R G$ dos demais animais taurinos, tradicionalmente utilizados como modelos em estudos de base comparativa ao Nelore (LEE et al., 2009).

A formação do tecido muscular é denominada miogênese e ocorre durante o desenvolvimento pré-natal, quando o processo de hiperplasia muscular (aumento em número das células musculares) se manifesta. Durante o desenvolvimento embrionário, células progenitoras miogênicas originam os mioblastos, células uninucleadas e ativas mitoticamente, que se diferenciam em célula muscular, mais comumente chamada de fibra muscular, a unidade estrutural essencial do músculo (CHARGÉ \& RUDNICKI, 2004; HOSSNER, 2005).

A miogênese é um passo fisiológico do crescimento animal determinado por fatores regulatórios de transcrição miogênica, também denominados de MRF's. Os fatores de transcrição mais conhecidos atualmente são o MyoD e o Myf-5, que são fatores primários agindo na determinação miogênica, ou seja, na transição das células miogênicas progenitoras em mioblastos (MEGENEY \& RUDNICKI, 1995). Já, a miogenina e o fator MRF4 atuam na fase de diferenciação, ou seja, quando os mioblastos se proliferam e se fundem para dar origem aos miotubos (CHARGÉ \& RUDNICKI, 2004). Todos esses fatores de transcrição são reguladores que controlam as etapas e passos da formação muscular, atuando num primeiro momento como ativadores da transcrição, ligando-se a sítios específicos do DNA e codificando para a produção de RNAm específicos. Além dos MRF`s, fatores de crescimento como IGF-I também podem estar relacionados com a miogênese, provavelmente via indução da miogenina (SABOURIN \& RUDNICKI, 2000). 
O músculo compreende tipos de fibras funcionalmente diversas, variando em tamanho, metabolismo e contratilidade (BLAAUW et al. 2013). O fenótipo muscular é amplamente definido pelo número de fibras, área de seção transversal, arquitetura muscular e distribuição do tipo de fibra. As fibras musculares dos mamíferos são amplamente classificadas como contração lenta (SO; Tipo I) ou contração rápida (FOG, Tipos IIa e FG, Tipo IIx). A seleção para o crescimento muscular, em geral, resulta em carne mais pálida devido ao maior proporção de fibras glicolíticas (Tipo IIx-“branca”), como no caso de animais DM (MOGHADAM et al., 2017; ROBINSON et al., 2017).

Para que ocorra crescimento ou acréscimo de músculo, a síntese proteica deve superar a degradação, ou seja, o turnover proteico corporal, que é um processo fisiológico dinâmico, energeticamente dispendioso e diretamente relacionado ao crescimento muscular. A síntese proteica ocorre em função do número de ribossomos e da taxa de produção de proteínas do tecido, enquanto a degradação é determinada por hormônios, como cortisol e glucagon, bem como, pelos processos proteolíticos corporais principais, tais como o proteossoma, enzimas cálcio-dependentes (calpaína/calpastatina) e lisossomais (catepsinas) (DELGADO et al., 2001; OUALI et al., 2006).

Além disso, Koohmaraie et al. (2002) propuseram mecanismos, pelos quais o tamanho da fibra muscular poderia ser modificado por meio de uma alteração no balanço entre a quantidade de proteína sintetizada e degradada. Em consequência, esse maior aumento do tamanho da fibra, foi uma consequência do aumento da síntese, superior à degradação proteica. Nessa situação, poderia ocorrer uma maior proteólise pós-morte e consequentemente aumento da maciez dos músculos.

Portanto, a deposição de músculo ocorre então quando há aumento na síntese ou redução na degradação. Ambos os fatores estão intrinsecamente relacionados à maciez da carne, que é modulada também, por condições físico-químicas, como $\mathrm{pH}$ e resfriamento, e também resultante da ação de enzimas proteolíticas dentre as quais tem sido dada atenção para as calpaínas, caspases, ou peptidases de serina, dentre outras, e é predita com maior acurácia pela quantidade e/ou atividade dos inibidores naturais dessas enzimas (SENTANDREU, COULIS \& OUALI, 2002). No que diz respeito a maior contribuição no amaciamento da carne, o sistema dependente de cálcio para ativação, formado pelas calpaínas e seu inibidor, calpastatina, parecem ser o que melhor explicam o fenômeno de maciez (DELGADO et al., 2001; KOOHMARAIE E GEESINK, 2006). Porém, é importante elucidar que outros sistemas também atuam favorecendo ou prejudicando a maciez em animais de produção, tais como 
caspases, proteasomas, catepsinas, proteínas de choque térmico, proteínas do estroma, dentre outros (OUALI, 2013).

Diante do exposto, têm sido demonstrado resultados positivos para a qualidade da carcaça e eficiência produtiva de bovinos de corte no Brasil, quando se promove o cruzamento entre raças de clima temperado que detém a característica de DM, como a RG, com as raças de clima tropical. Assim, geram-se animais mais produtivos e resistentes, podendo ainda explorar os efeitos da heterose e a complementariedade das raças, que podem estar relacionados não só a aspecto produtivo, como ganho de peso, musculosidade, peso de carcaça, precocidade, mas também ao aspecto qualitativo da carcaça, como conformação e maciez da carne (HAMMOUND, CHASE \& BOWERS, 1998).

\subsubsection{Características de Crescimento Animal}

Dentre os principais fatores considerados no processo de produção de carne, pode-se citar a taxa de crescimento animal, que é influenciada por genótipo e ambiente. Nesse processo, para a obtenção de eficiência biológica e econômica, é necessário oferecer aos animais condições para apresentarem satisfatório crescimento corporal, desde o nascimento até o momento do abate, possibilitando a máxima expressão do fenótipo (MORAES, 2001). Conforme Cruz et al. (2009) descreveram, estratégias de intensificação da produção de carne, com utilização de grupos geneticamente melhorados e com redução da idade de abate dos animais, contribuem para elevar a taxa de desfrute da pecuária de corte brasileira.

A proporção dos tecidos na carcaça no momento do abate é o aspecto da composição corporal que mais importa ao produtor e indústria, portanto, determina em grande parte o valor econômico da carcaça (BERG \& BUTTERFIELD, 1979). Em concordância, a raça, o sexo e a nutrição podem afetar o crescimento e a composição dos tecidos e, consequentemente, o peso ao abate. Esses são os fatores mais importantes que os produtores dispõem na tentativa de alterar a composição da carcaça, a fim de atingir um maior peso de carcaça e, assim, obter melhor retorno financeiro pelos frigoríficos.

A genética animal pode influenciar de diversas maneiras as características de qualidade da carcaça. As raças bovinas se diferem quanto às curvas de crescimento dos tecidos e, consequentemente, na velocidade de deposição de gordura. A partição da deposição de gordura nos diferentes depósitos corporais segue uma ordem cronológica sendo a gordura perirrenal a

primeira a ser depositada, seguida pela intermuscular, subcutânea e, finalmente, pela intramuscular (SAINZ \& HASTING, 2000). 
O crescimento é caracterizado pelo aumento da massa corporal em função do tempo, com a deposição de proteínas, gordura e minerais (OWENS et al., 1995). No que se refere aos genótipos, animais puros ou com grau de sangue taurino (Bos taurus) produzem carcaças mais pesadas, em contraste aos animais zebuínos (Bos indicus), devido ao maior crescimento, sobretudo muscular, o que reflete nos índices zootécnicos relacionados ao desempenho ponderal (MORALES et al., 2002).

Portanto, a combinação entre genótipos taurinos e zebuínos pode promover superioridade para características de desempenho, se comparada ao genótipo zebuíno puro, por meio do ganho em heterose e complementariedade entre as raças (CLIMACO et al., 2011).

Neste sentido, bovinos taurinos, como os da raça RG, vêm sendo introduzidos em cruzamentos com animais da raça Nelore, com o objetivo de melhorar as características quantitativas e qualitativas da carcaça. O genótipo de animais Bos taurus provém de animais com elevadas taxas de crescimento e desempenho superior, até mesmo em seus cruzamentos, em comparação aos animais Nelore puros (TAVEIRA et al., 2013).

Animais RG, por possuírem o fenótipo de DM, alteram o padrão de crescimento e desenvolvimento muscular, resultando em carcaças superiores, devido à maior produção de carne e maior proporção de cortes nobres (XAVIER, 2014). Além disso, animais DM tendem apresentar menor consumo e melhor conversão alimentar (ARTHUR, 1995), carcaças com menor proporção de gordura (tanto subcutânea, quanto intramuscular) que animais sem tal característica, maior porcentagem de cortes nobres, cerca de $30 \%$ a mais na relação músculo:osso, menor porcentagem de ossos, maiores rendimentos de carcaça e área de olho de lombo. (ARTHUR, 1995).

Ao analisarem sete raças de corte da Espanha quanto às características de carcaça, Albertí et al. (2005) observaram que a raça RG tendeu a produzir carcaças maiores, com pesos de abate mais elevados do que as outras raças. Os autores ainda qualificaram a raça RG como alta produtora de carne, com maturação tardia e carcaça curta, produzindo carcaças altamente musculosas e com baixa proporção de cobertura de gordura.

Em estudo conduzido por Sanchez et al. (2005b), o qual avaliou bovinos machos cruzados Rubia Gallega x Nelore e bovinos da raça Nelore, abatidos com média de 22 meses de idade, observou-se diferença de $94 \mathrm{Kg}$ no peso de carcaça entre os grupos genéticos, sendo maior para animais cruzados. Os bovinos cruzados apresentaram maior rendimento de carcaça $(62,24 \%)$ e maior área de olho de lombo $\left(95,80 \mathrm{~cm}^{2}\right)$, valores superiores aos encontrados para animais Nelore puro $\left(58,78 \%\right.$ e $55,15 \mathrm{~cm}^{2}$, respectivamente). 
De acordo com Sanchez et al. (1992), em estudo sobre características de composição corporal de animais da raça Rubia Gallega com 14 meses de idade, o rendimento médio de carcaça de animais RG $(61,07 \%)$ foi alto. As percentagens médias de músculo, osso e gordura foram de 74,01; 15,99 e 8,57\%, respectivamente e a relação músculo/osso de 4,68.

Portanto, a produção de animais originados desse cruzamento possibilita elevada taxa de crescimento muscular, carcaças mais pesadas com maior rendimento de peças comerciais e baixo conteúdo de tecido adiposo.

\subsubsection{Qualidade da carne}

O conceito de qualidade da carne é muito amplo e pode ser influenciado por diversos fatores que estão inter-relacionados dentro da cadeia de produção da carne, podendo esses serem afetados durante todas as etapas do processo produtivo, desde a concepção do animal até o consumo do produto final (LUCHIARI FILHO, 2000).

Segundo Koohmaraie et al. (2002), a qualidade da carne pode ser determinada a partir das propriedades físico-químicas, tais como maciez, sabor, cor, odor e suculência, determinadas por fatores inerentes ao indivíduo (genética, idade, sexo), ao local de origem (manejo alimentar, manejo geral), ao manejo pré-abate, abate e métodos de processamento da carcaça e da carne, como duração e temperatura de estocagem e, até mesmo, a forma de preparo.

A maciez é a característica mais importante que influencia a satisfação do consumidor quanto à palatabilidade da carne bovina, sendo o primeiro atributo procurado pelo consumidor (OUALI et al., 2013). Existem três fatores preponderantes na determinação da maciez: dureza intrínseca (genética/enzimas proteolíticas e teor/solubilidade de colágeno), fase de endurecimento e fase de amaciamento.

Enquanto as fases de endurecimento e amaciamento ocorrem durante período post mortem, a dureza intrínseca da carne já existe no momento do abate e não é alterada no decorrer do período post mortem (KOOHMARAIE \& GEESINK, 2006). A maciez da carne é influenciada por vários fatores, como raça, idade, conteúdo de gordura intramuscular, declínio do $\mathrm{pH}$ post mortem, tipo de fibra e tipo de músculo, além de outros fatores como quantidade e solubilidade do colágeno e ação de sistemas proteolíticos, que atuam na degradação de estruturas proteicas miofibrilares específicas (WHEELER, et al., 2001).

Autores relataram diferenças significativas na maciez da carne entre raças bovinas europeias e zebuínas (O'CONNOR et al., 1997). Crouse et al. (1993) observaram que a participação crescente de genes de Bos indicus em cruzamentos com Bos taurus diminui 
consideravelmente a maciez da carne. Essa variabilidade da maciez da carne entre as raças tem sido atribuída a diferentes níveis de enzimas proteolíticas encontradas nos músculos dos animais (WHIPPLE et al., 1990), especialmente enzimas do sistema das calpaínas. Bos indicus, quando comparados a Bos taurus, possuem maior atividade de calpastatina, essa, por sua vez, apresenta efeito inibidor sobre as calpaínas, reduzindo a atividade proteolítica e evitando o amaciamento da carne (GOLL et al., 1983).

Em estudo relacionando a taxa de crescimento de animais, Sazili et al. (2004) constataram que a taxa de $\mu$-calpaína foi significativamente reduzida no período pós-morte em grupos com altas taxas de crescimento. Entretanto, segundo esses autores não houve relação entre a taxa de crescimento e a força de cisalhamento, ou ainda, entre os níveis de $\mathrm{m}$ e $\mu$ calpaínas e a força de cisalhamento, embora os valores de força fossem positivamente relacionados com a intensidade de $135 \mathrm{kDa}$ de calpastatina até 24 horas pós-morte. Porém, outros autores afirmaram que, grupos animais, com altas taxas de crescimento, apresentaram carnes mais palatáveis e mais macias, sem alterar o sistema de calpaínas. A hipótese consiste em que no crescimento muscular, há uma elevação dos níveis de calpastatina suprimindo a taxa de $\mu$-calpaína (e talvez a de m-calpaína), na qual há uma alteração (redução) da degradação proteica, resultando em um aumento do crescimento muscular (KOOHMARAIE et al., 2002). Por outro lado, Thirkildsen et al.(2002) não encontraram relação entre a taxa de crescimento, atividade de calpastatina, $\mu$-calpaína ou m-calpaína, em carnes maturadas por 1 ou 7 dias.

Ao compararem animais zebuínos e taurinos britânicos, Martins et al. (2017) observaram que bovinos Nelore apresentam menor índice de fragmentação miofibrilar, comparados à raça britânica Angus (47,6 4 4,28\%, 69,2 \pm 4,28\%, respectivamente). Também avaliou-se a atividade da calpastatina, a expressão gênica e abundância de proteínas envolvidas no amaciamento da carne. Segundo os autores, a maior proteólise post mortem no músculo esquelético de bovinos Angus, não é causada por diferenças na expressão dos genes que codificam calpastatina ou calpaína, nem pela abundância dessas enzimas, mas sim devido à maior atividade da calpastatina no músculo esquelético de bovinos Nelore (MARTINS et al., 2017).

Oliete et al. (2006) constataram que a carne de animais Bos taurus apresentou intensa diminuição na força de cisalhamento a partir do primeiro dia até o $21^{\circ}$ dia de maturação, como esperado. A diminuição da força de cisalhamento está associada ao aumento do índice de fragmentação miofibrilar (MCDONAGH et al. 2001), o que é devido principalmente à degradação enzimática de proteínas miofibrilares (OUALI, 1990) e proteínas associadas a estas 
(KOOHMARAIE,1996). Assim, há uma contribuição multienzimática na proteólise post mortem para o amaciamento da carne, com consequente degradação de proteínas miofibrilares como titina, desmina, nebulina, troponina e tropomiosina (OUALI et al.,2013).

Rubensam et al. (1998) mostraram que à medida que a proporção de Bos indicus aumenta, ocorre uma redução na maciez da carne. Ao comparar músculos de Longissimus thoracis de bovinos Polled Hereford puros, 3/4 Hereford 1/4 Nelore e 5/8 Hereford 3/8 Nelore quanto à atividade de calpastatina e a força de cisalhamento, os autores observaram que a participação crescente do genótipo Bos indicus resultou em carne de pior maciez.

Sanchez et al. (2005b) avaliaram as características de qualidade das carcaças de animais F1 RGN, abatidos em média com 22 meses de idade. A carne dos animais cruzados apresentou menor força de cisalhamento $(6,57 \mathrm{~N})$ e obteve menor perda por exsudação (1\%) ao descongelamento. As cores da carne e da gordura foram mais claras e mais atrativas nos animais cruzados.

As perdas por cocção (PPC) também afeta diretamente a qualidade da carne bovina, interferindo diretamente na sua suculência (ZEOLA, 2002). Em estudos realizados por Sanchez et al. (2005b) e Silva (2011) avaliando machos F1 RGN abatidos aos 22 e 24 meses, os animais RGN apresentaram valores de PPC (30,41\% e 25,57\%, respectivamente) superiores aos animais Nelore, provavelmente devido às diferenças químicas da carne existentes entre esses dois grupos genéticos.

A genética do animal pode influenciar a qualidade da carne. As raças bovinas se diferem quanto às curvas de crescimento dos tecidos e, consequentemente, na velocidade de deposição de gordura. Os bovinos DM são animais de maturação tardia, caracterizados pelo baixo teor de gordura corporal, apresentando teor de gordura intramuscular inferior a 1\%. A deposição de gordura intramuscular pode interferir na percepção da maciez da carne, entretanto animais DM apresentam carne macia principalmente pelo baixo teor de colágeno (WIENER et al., 2009).

De acordo com Hanset (1982), os músculos do bovino DM têm menor quantidade de colágeno (tecido conectivo), comprovada pela redução de cerca de 20 a 30\% da quantidade de hidroxiprolina. Além disso, apresenta maior proporção de colágeno solúvel do que insolúvel o que implica diretamente na redução da resistência e, consequentemente, em maior maciez da carne (ARTHUR, 1995).

Heinemann et al. (2003), trabalhando com animais Nelore e cruzados Nelore x Limousin entre 18 e 24 meses, confinados por 204 dias e abatidos em diferentes pesos, concluíram que animais cruzados apresentaram quantidade de colágeno média inferior do que os animais 
Nelore. E a solubilidade do colágeno foi significativamente maior em animais mais jovens e mais leves, porém não resultou em melhor textura da carne desses animais.

Além da genética, a relação da taxa de crescimento e maciez da carne também pode ser esclarecida pelo desenvolvimento e estrutura do tecido conjuntivo. Harper (1999) sugeriu que uma menor formação de ligações cruzadas nos músculos em grupos com altas taxas de crescimento implicou em maior maciez da carne.

O atributo de qualidade também é determinado pelo estado de contração pós-rigor e pelo comprimento da unidade contráctil do músculo, o sarcômero (RAMOS \& GOMIDE, 2007). Durante a maturação há degradação das proteínas miofibrilares, o que leva a queda da tensão isométrica e consequentemente a carne apresenta maior maciez (PAULINO et al., 2014).

A maturação desempenha papel fundamental no processo de amaciamento da carne, devido à ativação de sistemas proteolíticos intracelulares, os quais agem sobre as proteínas miofibrilares (OUALI et al., 2006). Como já mencionado bovinos de raças européias, como $\mathrm{RG}$, possuem menor atividade de calpastatina resultando em maior atividade proteolítica das calpaínas, o que culmina em maior degradação da linha $\mathrm{Z}$ e consequentemente maior comprimento de sarcômero e maior maciez da carne.

A avaliação da cor da carne também é importante para avaliar se um produto é de qualidade. De acordo com Zeola et al. (2002) a cor da carne pode ser afetada por fatores como: tipo de músculo, raça, sexo, idade do animal e alimentação. Ainda segundo Felício (2015), em condições normais de conservação, a cor é o principal atrativo dos alimentos, já que reflete a quantidade e o estado químico da mioglobina $(\mathrm{Mb})$. A cor da carne irá variar de acordo com cada músculo, pois ela depende da proporção de fibras vermelhas e brancas da carne. Em animais DM, é predominante um maior número de fibras brancas, caracterizando carne mais clara (BOCCARD, 1982).

A análise das fibras musculares esqueléticas também está relacionada a qualidade da carne, por evidenciar o crescimento dos animais em razão da idade e as particularidades de desenvolvimento muscular de acordo com cada grupo genético. Pode-se observar diferenças no diâmetro, na quantidade e na quantidade das fibras em relação as raças bovinas europeias e zebuínas. Raças com fenótipo de DM possuem aumento do número de fibras musculares e ampliação individual dessas fibras (hiperplasia e hipertrofia, respectivamente), quando comparado ao bovino que não detém essa característica, isso contribui para maior maciez da carne (ARTHUR, 1995; GAGNIERE et al., 1997). Além disso, a carne de bovinos DM apresenta maior maciez devido à maior proporção de fibras glicolíticas (BOCCARD, 1982). 
Portanto, de acordo com os dados apresentados a qualidade da carne de raças bovinas europeias, em geral, é superior quando comparada a raças zebuínas. Diante disso, a crescente participação de genes de animais Bos taurus em cruzamentos com Bos indicus, aumentando consideravelmente a maciez da carne.

Por fim, os resultados de estudos avaliando as características descritas acima em animais cruzados, sugerem que deve haver maior investigação das diferenças entre os grupos genéticos em relação as características de produção e qualidade da carcaça e da carne, visto que é um assunto ainda pouco elucidado pela literatura. Desta forma, o maior entendimento do uso de cruzamentos industriais é essencial para aumento da eficácia da produção no Brasil, para elucidar assim os fatores genéticos, biológicos e fisiológicos relacionados às características qualitativas e quantitativas de interesse de produtores e consumidores. 


\section{REFERÊNCIAS}

ACRUGA. Annual summary. www.acruga.com. 2018.

ALBERTI, P.; RIPOLL, G.; GOYACHE, F.; LAHOZ, F.; OLLETA, J. L.; PANEA, B.; et al. Carcass characterization of seven Spanish beef breeds slaughtered at two commercial weights. Meat Science, v. 71, p. 514-521, 2005.

ARTHUR, P. F. Double muscling in cattle: a review. Australian Journal of Agricultural Research, v. 46, n.8, p.1493-1515, 1995.

BAILEY, A. J.; ENSER, M. B.; DRANSFIELD, E.; RESTALL, D. J.; AVERY, N. C. Muscle and adipose tissue from normal and double muscled cattle: Collagen Types, Muscle Fibre Diameter, Fat Cell Size and Fatty Acid Composition and Organoleptic Properties. Curr Top. Vet. Med. Animal Science, v.16, p. 178 - 202, 1982.

BLAAUW, B.; SCHIAFFINO, S.; REGGIANI, C. Mechanisms modulating skeletal muscle phenotype. Comprehensive Physiology, v. 3, p. 1645-1687, 2013.

BRADLEY, D. G.; LOFTUS,R. T.; CUNNIGHAM, E. P.; MACHUGH, D. E. Genetic and domestic cattle origins. Evolutionary Anthropology, v.6, p. 79-86, 1998.

BERG, R.T.; BUTTERFIELD, R.M. El crescimiento del ganado vacuno y la producción de carne de vacuno. Nuevos conceptos sobre desarrollo de ganado vacuno. Ed. Acribia: Zaragoza, España, 1979, 298p.

BOCCARD, R. Relationship between muscle hypertrophy and the composition of skeletal muscle. Curr Top. Vet. Med. Animal Science, v.16, p.148-161, 1982.

BRASIL. Decreto n $^{\circ}$ 9.013, de 29 de março de 2017. Dispõe sobre a regulamentação da Inspeção Industrial e Sanitária de Produtos de Origem Animal. Diário Oficial da União, Poder Executivo, Brasília, DF, 30 mar. Seção 1, p. 1.

BUAINAIN, A. M.; BATAlHA, M. O. Cadeia Produtiva da Carne Bovina. Brasília: Ministério da Agricultura, Pecuária e Abastecimento. Série de Agronegócios, v.8, p.86, 2007.

CATTELAM, J.; MENEZES, L. F. G.; FERREIRA, J. J. et al. Composição física da carcaça e qualidade da carne de novilhos e vacas de descarte de diferentes grupos genéticos submetidos a diferentes frequências de alimentação. Ciência Animal Brasileira, v.10, n.3, p.764-775, 2009.

CHARGÉ, S. B.; RUDNICKI, M. A. Cellular and molecular regulation of muscle regeneration. Physiological Reviews, v.84, n.1, p.209-238, 2004.

CLIMACO, S. M.; RIBEIRO, E. L. A.; MIZUBUTI, I. Y.; SILVA, L. D. F.; BARBOSA, M. A. A. F.; BRIDI, A. M.. Desempenho e características de carcaça de bovinos de corte de quatro grupos genéticos terminados em confinamento. Revista Brasileira de Zootecnia, v.40, n.7, p.1562-1567, 2011.

CROUSE, J. D.; CUNDIFF, L. V.; KOCH, R. M.; KOOHMARAIE, M.; SEIDEMAN, S. C. Comparisons of Bos indicus and Bos taurusinheritance for carcass beef characteristics 
and meat palatability. Beef Research, Progress Report, n.4, p.125-127, 1993.

CRUZ, G. M.; RODRIGUES, A. A.; TULliO, R. R.; ALENCAR, M.; ALLEONI, G. F.; OLIVEIRA, G. P.. Desempenho de bezerros da raça Nelore e cruzados desmamados recebendo concentrado em pastagem adubada de Cynodon dactylon cv. Coastcross. Revista Brasileira de Zootecnia, v.38, n.1, p.139-148, 2009.

DELGADO, E. F.; GEESINK, G. H.; MARCHELLO, J. A.; et al. The calpain system in three muscles of normal and callipyge sheep. Journal of Animal Science, v.79, n.2, p.398412, 2001.

EUCLIDES FILHO, K.; EUCLIDES, V. P. B.; FIGUEIREDO, G. R.; et al. Avaliação de animais Nelore e seus mestiços com Charolês, Fleckvieh e Chianina, em três dietas. 1. Ganho de peso e conversão alimentar. Revista da Sociedade Brasileira de Zootecnia, v.26, n.1, p. 66-72, 1997.

EUCLIDES FILHO, K.; FIGUEIREDO, G. R. Retrospectiva e perspectivas de cruzamentos no Brasil. In: Simpósio Brasileiro sobre cruzamento industrial, Londrina: IAPAR, p.1135, 2003.

FELÍCIO, P.E. Qualidade da carne bovina: características físicas e organolépticas. 2015. Disponível em: http://www.fea.unucamp.br/arquivos/sbz1.pdf. Acesso em 13/08/2019.

GAGNIERE, H.; PICARD, B.; JURIE C.; GEAY Y. Comparative study of metabolic differentiation of fetal muscle in normal and double-muscled cattle. Meat Science, v.45, n.2, p.145-152, 1997.

GMG Importação e exportação. , Disponível em: http://www.geneticaparatodos.com/historia.asp Acessado em: 09/05/2018, 2009a.

GMG Importação e exportação. Disponível em: http://www.geneticaparatodos.com/projeto_rubia.asp Acessado em: 09/05/2018, 2009b.

GOLL, A.; FERREY, D. R.; GLOSSMANN, H. Target size analysis of skeletal muscle Ca channels. Positive allosteric heterotropic regulation by d-cis-diltiazem is associated with apparent channel oligomer dissociation. FEBS Lett, v. 157, p. 63-69, 1988.

HAMMOUND, A. C.; CHASE, J. R.; BOWERS, E. J. Heat Tolerance in Tuli-Senepol and Brahman-Sired F1 Angus Heifers in Florida. Journal of Animal Science, v.76, n.6, p:15681577, 1998.

HAN, J.; FORREST, R. H.; HICKFORD, J. G. H. Genetic variations in the myostatin gene (MSTN) in New Zealand sheep breeds. Molecular Biology Reports, v. 40, n. 11, p. 63796384, 2013.

HANSET, R. Muscular hypertrophy as a racial characteristic: the case of the Belgian Blue breed. Curr Top. Vet. Med. Animal Science v.16, p. 437, 1982.

HARPER, G.S. Trends in skeletal muscle biology and the understanding of toughness in beef. Australian Journal of Agricultural Research, v.50, p.1105-1129, 1999.

HEINEMANN, R. J. B.; PINTO M. F.; ROMANELLI, P. F. Fatores que influenciam a 
textura da carne de novilhos Nelore e cruzados Limousin-Nelore. Pesquisa Agropecuária Brasileira, v.38, p.963-971, 2003.

HOSSNER, K. L. Hormonal regulation of farm animal growth. Department of Animal Sciences, Colorado State University, Fort Collins, Colorado, USA. CABI Publishing, 2005, p. 240.

KOOHMARAIE, M. Biochemical factors regulating the toughening and tenderization process of meat. Meat Science, v.43, n.1, p.193-201, 1996.

KOOHMARAIE, M.; SHACKELFORD, S.; VEISETH, E.; KENT, M. P.; WHEELER, T. L. Meat tenderness and muscle growth: is there any relationship. Meat Science, v.62, n.3, p.345-352, 2002.

KOOHMARAIE, M; GEESINK, G. H. Contribution of postmortem muscle biochemistry to the delivery of consistent meat quality with particular focus on the calpain system. Meat Science, v.74, n.1, p.34-43, 2006.

KOURY FILHO, W. Escores visuais e suas relações em características de crescimento em bovinos de corte. 80f. Tese (Doutorado em Zootecnia e Produção Animal) Universidade Estadual Paulista, Jaboticabal, 2005.

LAGE, J. F; PAULINO, P. V. R; VALADARES, FILHO, S. C; et al. Influence of genetic type and level of concentrate in the finishing diet on carcass and meat quality traits in beef heifers. Meat Science, v. 90, n.3, p.770-774, 2012.

LEE, C. Y.; HU, S. Y.; GONG, H. Y.; CHEN, M. H.; LU, J. K.; WU, J. L. Suppression of myostatin with vector-based RNA interference causes a doublemuscle effect in transgenic zebrafish. Biochemical and biophysical research communications, v.387, n.4, p. 766-771, 2009.

LUCHIARI FILHO, A. Pecuária da carne bovina. 1.ed. São Paulo: Albino Luchiari Filho, 134p, 2000.

MARTINS, T.; SANGLARD, L.; SILVA, W.; CHIZZOTTI, M.; LADEIRA, M.; SERÃO, N.; PAULINO, P. V. R.; DUARTE, M. Differences in skeletal muscle proteolysis in Nellore and Angus cattle might be driven by Calpastatin activity and not the abundance of Calpain/Calpastatin. The Journal of Agricultural Science, v. 155, p. 1669-1676, 2017.

MATSAKAS, A.; PATEL, K. Intracellular signalling pathways regulating the adaptation of skeletal muscle to exercise and nutritional changes. Histology and histopathology, v. 24, n. 2, p. 209-222, 2009.

MEGENEY, L. A.; RUDNICKI, M. A. Determination versus differentiation and the MyoD family of transcription factors. Biochem Cell Biol, v.73, n.9-10, p.723-732, 1995.

METZ, P. A. M.; MENEZES, L. F. G.; SANTOS, A. P. Perfil de ácidos graxos na carne de novilhos de diferentes idades e grupos genéticos terminados em confinamento. Revista Brasileira de Zootecnia, v.38, n. 3, p. 523-531, 2009.

McDONAGH, M. B.; HERD, R. M.; RICHARDSON, E.C.; OLLY, U. H.; ARCHER, J.A.; ARTHUR, P.F. Meat quality and the calpain system of feedlot steers following a single 
generation of divergent selection for residual feed intake. Australian Journal of Experimental Agriculture, v.41, n.7, p. 1013-1021, 2001.

McPHERRON, A. C.; LEE, S. J. Double muscling in cattle due to mutations in the myostatin gene. Proceedings of the National Academy of Sciences of United States of America, v. 94, n.23, p. 12457-12461, 1997.

MOGHADAM, H. K.; JOHNSEN, H.; ROBINSON, N.; ANDERSEN O.; JORGENSEN, E. H.; JOHNSEN, H. K.; BAEHR,V. J.; TVEITEN, H. Impacts of early life stress on the methylome and transcriptome of Atlantic salmon. Scientific Reports, v. 7, p. 5023, 2017.

MORAES, S.S. Novos microelementos minerais e minerais quelatados na nutrição de bovinos. Documentos 119. Embrapa. Campo Grande - MT. p. 11. 2001.

MORALES, D.C.; CHARDULO, L. A. L.; SILVEIRA.A.C.; OLIVEIRA, H.N., ARRIGONI, M.B.; MARTINS, C.L.; CERVIERI, R.C. Características de qualidade de carne de bovinos de corte de diferentes tamanhos à maturidade submetidos ao sistema superprecoce. Acta Scientiarum, v. 24, n. 4, p. 1-2, 2002.

O'CONNOR, S. F.; TATUM, J. D.; WULF, D. M. Genetic effects on beef tenderness in Bos indicus composite and Bos taurus cattle. Journal of Animal Science, v.75, n.10, p. 1822 $1830,1997$.

OLIETE, B.; MORENO, T.; CARBALLO, J.A et al.. Estúdio de lacalidad de la carne de ternera de raza Rubia Gallega a lo largo de lamaduración al vacio. Archivos de Zootecnia, v.55, n.209, p.3-14, 2006.

OUALI, A. Meat tenderization: Possible causes and mechanisms. Journal Muscle Foods, v. 1, n. 2, p. 129-165, 1990.

OUALI, A.; HERRERA-MENDEZ, C. H.; COULIS, G.; BECILA, S.; BOUDJELLAL, A.; AUBRY, L.; SENTANDREU, M. A. Revisiting the conversion of muscle into meat and the underlying mechanisms. Meat Science, v. 74, p. 44-58, 2006.

OUALI, A.; GAGAOUA, M.; BOUDIDA, Y.; BECILA, S.; BOUDJELLAL, A.; HERRERA-MENDEZ, C. H.; SENTANDREU, M. A. Biomarkers of meat tenderness: present knowledge and perspectives in regards to our current understanding of the mechanisms involved. Meat Science, v.95, n.4, p.854-70, 2013.

OWENS, F. N.; GILL, D. R.; SECRIST, D. S.; COLEMAN, S. W. Review of some aspects of growth and development of feedlot cattle. Journal of Animal Science, v.73, n.10, p. 3152-3172, 1995.

PAULINO, P. V. R.; OLIVEIRA, I. M.; BENATTI, J. M. B. Obtenção de carcaças bovinas superiores através do manejo nutricional. XXIV CONGRESSO BRASILEIRO DE ZOOTECNIA. Universidade Federal do Espírito Santo Vitória ES, 12 a 14 de maio de 2014.

PEREIRA, A. S. C.; BALDI, F.; SAINZ, R. D.; UTEMBERGUE, B. L.; CHIAIA, H. L. J.; MAGNABOSCO, C. U.; MANICARDI, F. R.; ARAUJO, F. R. C.; GUEDES, C. F.; MARGARIDO, R. C.; LEME, P. R.; SOBRAL, P. J. A. Growth performance, and carcass and meat quality traits in progeny of Poll Nellore, Angus and Brahman sires under tropical conditions. Animal Production Science, v. 55, p. 1295-1302, 2015. 
PEREIRA, J. C. C. Contribuição genética do zebu na pecuária bovina do Brasil. Informe Agropecuário, v.21, n.205, p.30-38, 2000.

PRINGLE, T. D; HARRELSON, J. M; WEST, R. L; WILLIAMS, S. E; JOHNSON, D. D. Calcium-activated tenderization of strip loin, top sirloin, and top round steaks in diverse genotypes of cattle. Journal of Animal Science, v. 77, n. 12, p. 3230-3237, 1999.

PRINGLE, T. D; WILLIAMS, S. E; LAMB, B. S; JOHNSON, D. D; WEST, R. L. Carcass Characteristics, the calpain proteinase system, and aged tenderness of Angus and Brahman crossbred steers. Journal of Animal Science, v.75, n. 11, p. 2955-2961, 1997.

RAMOS, E. M.; GOMIDE, L. A. M. Avaliação da qualidade de carnes. Fundamentos e metodologia. Viçosa: Ed UFV, 2007. p. 599.

ROBINSON, N. A.; TIMMERHAUS, G.; BARANSKI, M.; ANDERSEN, O.; TAKLE, H.; KRASNOV, A. Training the salmon's genes: influence of aerobic exercise, swimming performance and selection on gene expression in Atlantic salmon. BMC Genomics, v. 18, p. $971,2017$.

RUBENSAM, J. M.; FELÍCIO, P. E.; TERMIGNONI, C. Influência do genótipo Bos indicus na atividade de calpastatina e na textura da carne de novilhos abatidos no sul do Brasil. Ciência e Tecnologia de Alimentos, Campinas, v.18, n. 4, p. 405-409, 1998.

SABOURIN, L. A.; RUDNICKI, M. A. The molecular regulation of myogenesis. Clinical Genetics, v. 57, n. 1, p. 16-25, 2000.

SAINZ, R. D.; HASTING, E. Simulation of the development of adipose tissue in beef cattle. In: MCNAMARA, J. P.; FRANCE, J.; BEEVER, D. E.(Ed). Modeling nutrient utilization in farm animals. New York: CABI, 2000. p.175-182.

SANCHEZ, L.; CARBALlO, J. A.; SANCHEZ, B. Y et al. Características de la canal y de la carne de machos procedentes delcruce de Rubia Gallega com Nelore. Archivos de Zootecnia, v. 54, n. 206, p. 485-489, 2005a.

SANCHEZ, L.; BECERRA, J. J.; IGLESIAS, A. et al. Valoración del crecimiento em animales cruzados de Rubia Gallega com Nelore. Archivos de Zootecnia, v.54, n. 206, p. 497- 500, 2005b.

SANCHEZ, L.; SUEIRO, R. M., VALLEJO, V. M. Crecimiento y características de la canal em amojos de la raza Rubia Gallega. Rendimientos y composicion de la canal. Archivos de Zootecnia, v. 41, p. 241-255, 1992.

SARCINELLI, M. F.; VENTURINI, K. S.; SILVA, L. C. Produção de Bovinos: tipo carne. Boletim Técnico - PIEUFES: 00307. Universidade Federal do Espírito Santo, 2007.

SAZILI, A. Q.; LEE, G. K.; PARR, T.; SENSKY, P. L.; BARDSLEY, R. G.; BUTTERY, P. J. The effect of altered growth rates on the calpain proteolytic system and meat tenderness in cattle. Meat science, v. 66, p. 195-201, 2004.

SENTANDREU, M. A; COULIS, G.; OUALI, A. Role of muscle endopeptidases and their inhibitors in meat tenderness. Trends in Food Science \& Technology, v.13, n. 12, p. 400421, 2002. 
SILVA, M. J. F. B. Rendimento da carcaça e características físicas da carne de animais cruzados entre as raças Rubia Gallega e Nelore. 2011. 47f. Dissertação (Mestrado em Zootecnia) - Universidade Federal Rural de Pernambuco, Departamento de Zootecnia, Recife, 2011.

TAVEIRA, R. Z.; SILVEIRA NETO, O. J.; AMARAL, A .G. et al. Comparação de desempenho de bovinos Nelore e mestiços Nelore-Rubia Gallega em sistema de confinamento. Anais da Semana do Curso de Zootecnia - SEZUS v.8, p.243-255, 2013.

THIRKILDSEN, M.; MELCHIOR LARSEN, L.; BANG, H. G.; VESTERGAARD, M. Effect of growth rate on tenderness rate on tenderness development and final tenderness of meat from Friesian calves. Animal Science, v.74, p.253-264, 2002.

USDA, National Agricultural Statistics Service (2019). Agricultural Statistics Board, by the National Agricultural Statistics Service (NASS).

UYTTERHAEGEN, L.; CLAEYS, E.; DEMEYER, D.; LIPPENS, M.; FIEMS, L.O.; BOUCQUE, C.Y.; VANDERVOORDE, G.; BASTIAENS, A. Effects of double-muscling on carcass quality, beef tenderness and myofibrillar protein degradation in Belgian Blue and White bulls. Meat Science, v. 38, n. 2, p. 255-267, 1994.

WEBER, T.; RORATO, P. R. N.; LOPES, J. S. et al. Parâmetros genéticos e tendências genéticas e fenotípicas para características produtivas e de conformação na fase prédesmama em uma população da raça Aberdeen Angus. Revista Brasileira de Zootecnia, v.38, n.5, p.832-842, 2009.

WEST, R.L. Red to white fiber ratios as an index of double muscling in beef cattle. Journal of Animal Science, v. 38, n. 5, p. 1165-1175, 1974.

WHEELER, T.L.; SHACKELFORD, S.D.; CASAS, E.; CUNDIFF, L.V; KOOHMARAIE, M. The effects od Piemontese inheritance and myostatin genotype on the palatability of longissimus thoracis, gluteus medius, semimembranous, and biceps femoris. Journal of Animal Science, v. 79, p. 30-69, 2001.

WHEELER, T. L; SAVELL, J. W.; CROSS, H. R; LUNT, D. K; SMITH, S. B. Mechanisms associated with the variation in tenderness of meat from Brahman and Hereford cattle. Journal of Animal Science, v. 68, p. 4206-4220, 1990.

WHIPPLE, G.; KOOHMARAIE, M.; DIKEMAN, M. E.; CROUSE, J. D.; HUNT, M. C.; KLEMM, R. D. Evaluation of attributes that affect longissimus muscle tenderness in Bos taurus and Bos indicus cattle. Journal of Animal Science, v. 68, p. 2716-2728, 1990.

WIENER, P.; WOOLLIAMS, J. A.; FRANK-LAWALE, A.; RYAN, M.; RICHARDSON, R. I.; NUTE, G. R.; WOOD, J. D.; HOMER, D.; WILLIAMS, J. L. The effects of a mutation in the myostatin gene on meat and carcass quality. Meat Science, v. 83, p. 127-134, 2009.

XAVIER, S. R. Prospecção de Polimorfismo no Gene da Miostatina em Bovinos da Raça Senepol. 2014. Dissertação (Mestrado em Zootecnia). Universidade Federal do Mato Grosso do Sul, 2014.

ZEOLA, N. M. B. L. Conceitos e parâmetros utilizados na avaliação da qualidade da carne ovina. Revista Nacional da Carne, São Paulo, v. 26, n. 304, p. 36-56, 2002. 


\section{CAPÍTULO 2}

Desempenho, características de carcaça e qualidade de carne de bovinos Nelore e cruzados Rubia Gallega X Nelore 


\section{RESUMO}

Objetivou-se neste estudo avaliar e comparar a taxa de crescimento, desempenho, características de carcaça e qualidade da carne de bovinos Nelore e cruzados Rubia Gallega e Nelore. Foram utilizados 16 Nelore (N) e 16 Rubia Gallega x Nelore (RGN), machos não castrados, com peso médio inicial de $280 \mathrm{~kg} \pm 15 \mathrm{~kg}$ e $11 \pm 2$ meses de idade, confinados por 120 dias. Os bovinos receberam duas dietas, terminação 1 - 70\% de concentrado, e terminação 2 - $85 \%$ de concentrado. Foi avaliada a ingestão de matéria seca (IMS), ganho de peso médio diário (GMD) e eficiência alimentar (EA). No abate foi determinado o peso de carcaça quente (PCQ) e o rendimento de carcaça (RC). Durante a desossa foi analisado o pH, área do olho de lombo (AOL), espessura de gordura subcutânea (EGS), marmorização (MARB) e coletadas amostras para a análise do tipo, número e diâmetro de fibras musculares, perdas por cocção (PPC), maciez objetiva (FC), maciez subjetiva (sensorial), cor, lipídios totais (LT) e colágeno, no músculo Longissimus thoracis (LTH). Bovinos RGN apresentaram melhor desempenho e características de carcaça superiores a N (P<0,05), com $500 \mathrm{~g}$ de GMD a mais por dia e, RC 1,3\% maior. Observou-se interação linear para EGS, avaliadas por ultrassom, com a evolução do tempo de confinamento $(\mathrm{P}<0,05)$. Houve diferença entre os grupos genéticos para FC, PPC, cor $\left(\mathrm{L}^{*}, \mathrm{a}^{*}\right.$ e $\left.\mathrm{b}^{*}\right)$ e LT $(\mathrm{P}<0,05)$, indicando menor FC e LT na carne de animais cruzados. Não foram encontradas alterações na quantidade de colágeno e no número e diâmetro das fibras musculares $(\mathrm{P}>0,05)$. Também não houve diferença sensorial na carne dos diferentes grupos. O uso do cruzamento entre Bos taurus continental e Bos indicus potencializa a produtividade, proporcionando maior taxa de crescimento muscular, no entanto, não gera grandes influências na qualidade da carne, mas pode ser uma alternativa ao consumidor que busca alimentos com menor conteúdo de gordura.

Palavras-chave: Bos indicus, dupla musculatura, maciez, colágeno, fibra. 


\subsection{INTRODUÇÃO}

O Brasil tornou-se, nos últimos anos, o maior exportador de carne bovina do mundo (USDA, 2019). Entretanto, ainda são necessários avanços tecnológicos para melhorar a qualidade do produto final, bem como, a implantação de estratégias para conquistar e consolidar novos mercados. A demanda por produtos de origem animal de boa qualidade e saudáveis para o consumo humano tem aumentado nos últimos anos (TROY et al., 2016). A maciez é um dos atributos mais importantes para definir qualidade da carne e garantir aceitação e satisfação dos consumidores (KOOHMARAIE et al., 2002).

Essas melhorias podem ser obtidas com a intensificação do sistema de produção, com a redução na idade de abate que acarreta expressivos benefícios sobre a eficiência alimentar e a qualidade da carne e utilizando genótipos mais produtivos que produzam carne que atenda as exigências do mercado consumidor (RESTLE et al., 2000). Assim, o uso de ferramentas mais eficientes tal como o cruzamento industrial é uma alternativa para modificar a composição genética do rebanho, melhorando a produtividade e a qualidade do produto final.

O cruzamento entre raças europeias (Bos taurus) e raças zebuínas (Bos indicus) proporciona a obtenção de animais adaptados ao clima tropical, melhores em aspectos produtivos (ganho de peso, musculosidade, peso de carcaça, precocidade) e potencialmente produtores de carne de qualidade (EUCLIDES FILHO \& FIGUEIREDO, 2003). A utilização de diferentes raças visa à exploração da heterose e da complementaridade entre as raças (PEREIRA, 2012).

A raça Nelore é a mais difundida na bovinocultura de corte no Brasil e tem grande importância no crescimento da pecuária nacional, em razão de sua adaptabilidade às características climáticas e ao elevado desafio nutricional (KOURY FILHO, 2005; MARCONDES et al., 2009). No entanto, a carne de animais zebuínos tem sido relatada como de qualidade inferior ou com ampla variabilidade na maciez, devido principalmente à atividade reduzida da micro-calpaína na degradação das miofibrilas e alta atividade da calpatastina, reduzindo a proteólise post mortem e impactando negativamente na maciez da carne, quando comparados a animais de raças puras taurinas (RUBENSAM et al., 1998; KOOHMARAIE, 1994; MARTINS et al., 2017). Esse fato pode ser alterado pelo uso de estratégias como o cruzamento entre os bovinos da raça Nelore e raças europeias, explorando características complementares desses genótipos.

Diante disso, vem sendo utilizada a raça Rubia Gallega (Bos taurus continental) para cruzamento com animais Nelore, com o propósito de melhorar as características quantitativas 
e qualitativas da carcaça e intensificar a produção de carne de qualidade (ALBERTÍ et al., 2005).

A raça Rubia Gallega apresenta alta taxa de crescimento e baixa deposição de gordura (MONSERRAT \& SÁNCHEZ, 2000), com maturidade tardia, podendo se adaptar em ambientes diversos (ALBERTÍ et al., 2005). Uma característica favorável para a qualidade de carne é que bovinos Rubia Gallega podem apresentar fenótipo de dupla musculatura (DM), decorrente de mutações no gene miostatina (MSTN), que gera aumento da massa muscular podendo influenciar as características da carne (XAVIER, 2014). O fenótipo de DM foi identificado por pesquisadores em diversas raças bovinas, tais como Blond d'Aquitaine, Limousin, Charolês e Piemontês (SMITH et al., 2000; PHOCAS, 2009).

Assim, para o país conquistar novos mercados, é necessário que o setor tenha bom desempenho produtivo e seja eficiente para disponibilizar produtos de qualidade. A fim de alcançar esses avanços, é fundamental adequar recursos genéticos, ambientais, de manejo e de mercado. Nesse contexto, torna-se importante estudos visando particularmente o impacto do cruzamento industrial sobre o desempenho animal e as características de qualidade da carcaça e da carne, para fornecer subsídios aos sistemas de produção de carne do país.

Com base nesses estudos, espera-se que os animais cruzados Bos taurus continental x Bos indicus de DM apresentem melhores aspectos quantitativos e qualitativos da carne, quando comparados aos animais Bos indicus. Portanto, o objetivo desse trabalho foi caracterizar o desempenho, as características de carcaça e a qualidade de carne de bovinos Nelore e cruzados Rubia Gallega x Nelore confinados.

\subsection{MATERIAL E MÉTODOS}

\subsubsection{Local de execução}

O experimento foi desenvolvido no Laboratório de Pesquisa em Gado de Corte da Faculdade de Medicina Veterinária e Zootecnia da Universidade de São Paulo - FMVZ/USP, em Pirassununga, SP. As análises quantitativas e qualitativas da carne foram realizadas na Faculdade de Zootecnia Engenharia de Alimentos FZEA/USP, Pirassununga - SP e na Faculdade de Medicina Veterinária e Zootecnia FMVZ/USP, Pirassununga - SP. O estudo teve a aprovação do Comitê de Ética em pesquisa da FZEA sob protocolo 6849090518. A análise sensorial, realizada no Laboratório de Análise Sensorial do Departamento de Engenharia de Alimentos da FZEA/USP, Pirassununga - SP, foi aprovada pelo Comitê de Ética em pesquisa da FZEA sob protocolo 24355219.0.0000.5422. 


\subsubsection{Animais, dietas e instalações}

Foram utilizados 16 bovinos Nelore (N) e 16 bovinos F1 Rubia Gallega x Nelore (RGN), machos não castrados, com idade média de 11 meses e $280 \pm 15 \mathrm{~kg}$ de peso corporal inicial. Os animais pertencentes ao grupo genético $\mathrm{N}$ eram meio irmãos, filhos de um único touro Nelore e de vacas dessa mesma raça, e os animais pertencentes ao grupo RGN também eram meio irmãos, filhos de um único touro (Conde AG, CG11420), pertencente à raça Rubia Gallega e de mães da raça Nelore. As progênies utilizadas eram pertencentes ao mesmo grupo contemporâneo e de manejo, foram selecionadas a partir do rebanho da Prefeitura Administrativa do Campus Fernando Costa da Universidade de São Paulo, Pirassununga, Brasil.

Os animais foram pesados, vermifugados e vacinados (clostridioses e aftosa) e identificados individualmente. Os animais foram mantidos dois a dois em baias $\left(15 \mathrm{~m}^{2}\right)$ parcialmente cobertas, com cochos e bebedouros, onde receberam alimentação ad libitum. Os primeiros 21 dias foram para a adaptação dos animais à dieta e à estrutura do confinamento, os animais receberam concentrado de forma gradual, até atingir os níveis previstos de volumoso: concentrado. Os bovinos foram alimentados duas vezes ao dia com a mesma dieta, primeiramente foi fornecido a terminação 1 por 50 dias, dieta proteica contendo $30 \%$ de volumoso e $70 \%$ de concentrado e, em seguida, foi fornecida a terminação 2 por 70 dias, dieta energética contendo $15 \%$ de volumoso e $85 \%$ de concentrado na dieta (Tabela 1). Todas as

dietas foram formuladas para atender todas as exigências nutricionais de bovinos em terminação, de acordo com as demandas nutricionais estimadas pelo uso do software Ração de Lucro Máximo (RLM, Esalq, USP, Piracicaba, São Paulo, Brasil). Foi utilizado no sistema CNCPS, um banco de dados de animais com exigência semelhante à de animais da raça Rubia Gallega. O ajuste da oferta de alimento foi realizado diariamente com base na avaliação das sobras do dia anterior, com uma oferta $5 \%$ superior ao consumo observado. 
Tabela 1. Composição das dietas experimentais (\%MS)

\begin{tabular}{lcc}
\hline Ingrediente & Terminação $\mathbf{1}^{\mathbf{2}}$ & Terminação 2 $^{\mathbf{3}}$ \\
\hline Silagem de milho & 21,00 & 4,400 \\
Bagaço de cana & 9,000 & 10,00 \\
Milho moído & 55,80 & 61,00 \\
Farelo de soja 45\% & 10,00 & 1,150 \\
Caroço de algodão & - & 20,00 \\
Núcleo' & 2,000 & 1,250 \\
Ureia & 1,300 & 0,800 \\
Cloreto de Potássio & 0,300 & 0,600 \\
Calcário & 0,600 & 0,800 \\
& Composição Química* & \\
MS & 61,53 & 77,17 \\
PB & 15,53 & 13,25 \\
NDT & 73,40 & 78,88 \\
FDN & 17,87 & 16,14 \\
FDA & 0,595 & 0,694 \\
\hline
\end{tabular}

Formulada pelo Programa Ração de Lucro Máximo 3.2® (RLM) ESALQ-USP

${ }^{1}$ Composição por quilograma de produto: cálcio $(\mathrm{g}) 188$; cobalto $(\mathrm{mg}) 24$; cobre $(\mathrm{mg}) 720$; enxofre (g) 74; flúor (mg) 240; fósforo (g) 24; iodo (mg) 40; magnésio (g) 30; manganês (mg) 1500; selênio (mg) 8; sódio (g) 60; zinco (mg) 2080; monensina sódica (mg) 1820.

${ }^{2}$ Oferecida entre $1^{\circ}-50^{\circ}$ dias de confinamento.

3Oferecida entre $51^{\circ}-120^{\circ}$ ou $127^{\circ}$ dias de confinamento.

*Estimado a partir do software RLM.

A ingestão de matéria seca foi avaliada diariamente em cada baia, por meio da pesagem do alimento fornecido e da pesagem das sobras antes do trato da manhã do dia seguinte fazendose a média de consumo por animal. A determinação da matéria seca da dieta total foi efetuada todos os dias para obtenção do consumo diário em quilos de matéria seca, que também foi expresso em porcentagem do peso vivo.

Durante os 120 dias de período experimental, foram avaliadas as características de desempenho: ingestão de matéria seca (IMS), peso vivo médio inicial (PI), peso vivo médio final (PF), ganho de peso médio diário (GMD) e eficiência alimentar (EA).

\subsubsection{Ultrassom}

Ao início do experimento e a cada 28 dias aproximadamente, foi avaliada por ultrassonografia, a área do músculo Longissimus thoracis (AOLU), espessura de gordura sobre o músculo Longissimus thoracis (EGSU) na região entre a $12^{\mathrm{a}}$ e a $13^{\mathrm{a}}$ costelas e espessura de gordura sobre o músculo Bíceps femoris (EGPU), entre o ílio e o ísquio, utilizando-se um 
equipamento de ultrassom, marca Aloka, modelo SSD 500 Micrus (AlokaCo. Ltda.), com transdutor linear de $3,5 \mathrm{mHz}$ e 17,2 cm de comprimento. As imagens foram analisadas utilizando o software Lince ${ }^{\text {. }}$

\subsubsection{Abate, desossa e coleta de amostras}

Ao final do período de confinamento (120 dias), os animais foram abatidos no Abatedouro Escola da Universidade de São Paulo, em Pirassununga/SP. Os procedimentos de abate foram realizados de acordo com o regulamento da inspeção industrial e sanitária de produtos de origem animal do Ministério da Agricultura, Pecuária e Abastecimento (BRASIL, 2017).

Antes do abate os animais permaneceram em jejum de sólidos por 18 horas recebendo apenas dieta hídrica ad libitum, foram transportados, de acordo com os tratamentos, não ocorrendo mistura de lotes no transporte ou nos currais do abatedouro.

Foram coletadas, na linha de abate, amostras do músculo Longissimus thoracis, e armazenadas imediatamente em $\mathrm{N}$-hexano, em seguida foram congeladas em nitrogênio líquido, e por fim mantidas em freezer $-80^{\circ} \mathrm{C}$ até o momento da análise para determinação do dos tipos de fibras musculares pela técnica da NADH-TR diaforase.

Durante o abate, as carcaças foram pesadas para obtenção do peso de carcaça quente $(\mathrm{PCQ}, \mathrm{kg})$ e cálculo de rendimento de carcaça $(\mathrm{RC}, \%)$. Em seguida, foram conduzidas à câmara fria, permanecendo a uma temperatura de 0 a $2^{\circ} \mathrm{C}$, por 24 horas. Posteriormente, as carcaças foram novamente pesadas, obtendo-se o peso de carcaça fria ( $\mathrm{PCF}, \mathrm{kg}$ ) e avaliando-se o $\mathrm{pH}$ ( $\mathrm{pH}$ $24 \mathrm{~h})$.

Durante a desossa foram avaliadas a área de olho de lombo $\left(\mathrm{AOL}, \mathrm{cm}^{2}\right)$, espessura de gordura subcutânea (EGS, mm), marmorização (MARB) e a cor ( $\mathrm{L}^{*}, \mathrm{a}^{*}$ e b*) no músculo Longissimus thoracis, entre a $12^{\mathrm{a}}$ e $13^{\mathrm{a}}$ costelas. Amostras de $2,54 \mathrm{~cm}$ de espessura do mesmo músculo foram coletadas, embaladas a vácuo individualmente e congeladas $-20^{\circ} \mathrm{C}$ para posteriores análises de perdas por cocção (PPC,\%), colágeno $(\mathrm{mg} / \mathrm{g})$, lipídios totais (LT, \%), maciez objetiva/força de cisalhamento (FC, $\mathrm{N}$ ) e maciez subjetiva (sensorial).

Para as análises de FC e PPC, as amostras foram maturadas por 24 h, 7, 14 e 21 dias em câmara de maturação a aproximadamente $2^{\circ} \mathrm{C}$. Para a análise de maciez subjetiva, os bifes foram maturados por 14 dias a $2^{\circ} \mathrm{C}$.

\subsubsection{Rendimento de carcaça quente}

$\mathrm{O}$ rendimento de carcaça quente $(\mathrm{RC} \%)$ foi calculado por meio dos dados obtidos por 
meio da relação entre o peso vivo dos animais e o peso de carcaça quente, em porcentagem.

\subsection{6 pH}

Foram determinados o $\mathrm{pH}(\mathrm{pH} 24 \mathrm{~h})$ no músculo Longissimus thoracis de cada meia carcaça direita, na altura da $12^{\mathrm{a}}$ costela, utilizando-se um pHgômetro digital com sondas de penetração (Hanna Instruments Inc®, modelo HI 99163).

\subsection{7 Área de olho de lombo e espessura de gordura subcutânea}

Cada meia-carcaça direita foi cortada entre a $12^{\mathrm{a}}$ e a $13^{\mathrm{a}}$ costelas para avaliar a área de olho de lombo (AOL) e a espessura de gordura subcutânea (EGS). Para AOL foi utilizada régua quadriculada específica, com escala $\mathrm{em}^{2} \mathrm{~cm}^{2}$, pelo método de quadrante de pontos. A espessura de gordura subcutânea (EGS) foi avaliada utilizando um paquímetro digital 6" (mod. ZAAS Precision, marca Amatools).

\subsection{8 Índice de Marmorização}

A avaliação da marmorização (MARB) foi realizada no músculo Longissimus thoracis, por meio de uma análise de escore visual subjetivo (USDA QUALITY GRADE, 1999), com a existência de depósitos de gordura entre as fibras musculares no músculo Longissimus thoracis, cuja classificação foi determinada por um escore.

\subsubsection{Cor}

A cor foi avaliada na região interna dos cortes após 20 min para tempo de blooming. A análise foi realizada em três pontos distintos da amostra, com um colorímetro portátil (mod. MiniScan EZ, marca Hunter Lab) com fonte de luz D65, ângulo de observação de $10^{\circ}$ e abertura da célula de medida de $30 \mathrm{~mm}$, usando-se a escala L*, a*, b* do sistema CIELab (HOUBEN et al., 2000).

\subsubsection{Maciez objetiva e perdas por cocção}

Para a determinação da força de cisalhamento (FC, N), os bifes foram cozidas, de acordo com os procedimentos realizados segundo Wheeler et al. (2015). As amostras foram assadas em forno elétrico a $180^{\circ} \mathrm{C}$, até atingirem a temperatura interna no bife de $71^{\circ} \mathrm{C}$. As temperaturas internas foram analisadas por meio de um sistema de termopares com termômetros individuais, que foram inseridos no centro geométrico dos bifes. Após assados, os bifes foram embalados individualmente e armazenados em refrigerador doméstico por 24 horas. Em seguida, foram 
retirados seis cilindros de $12 \mathrm{~mm}$ de diâmetro de cada amostra, com um vazador elétrico (WHEELER, SHACKELFORD \& KOOHMARAIE, 2001). A FC (N) foi determinada com equipamento texturômetro Brookfield ${ }^{\circledR}$ CT-3 Texture Analyser (Brookfield, EUA), equipado com lâmina Warner-Bratzler,para avaliação da maciez objetiva de cortes cárneos.

As perdas por cocção (PPC) foram determinada pela diferença de peso antes e depois do cozimento $[\mathrm{PPC}=(\mathrm{Pi}-\mathrm{Pf}) / \mathrm{Pi}]$, expressa em \%, conforme proposto por Honikel $(1998)$.

\subsubsection{Determinação de lipídios totais}

A análise dos lipídios totais (LT) foi realizada em amostras não maturadas de Longissimus thoracis. Foram usadas amostras cruas totalmente trituradas em um processador (Modelo Mixer Walita RI1364 com microprocessador - Philips do Brasil LTDA, Divisão Walita - Varginha, Minas Gerais). Em seguida, foram pesados 3 gramas de cada amostra e colocados em um erlenmeyer, no qual foram adicionados os reagentes para a extração dos lipídios totais, de acordo com a metodologia de Bligh \& Dyer (1959).

\subsubsection{Determinação histológica de número e diâmetro de tipo de fibras musculares}

Amostras do músculo Longissimus thoracis foram coletadas logo após o abate. Foram coletados seis fragmentos de cada animal. Imediatamente após a coleta, as amostras foram colocadas em OCT e congeladas em nitrogênio líquido, e mantidas em freezer $-80^{\circ} \mathrm{C}$.

Os cortes histológicos seriados com espessura de $12 \mu \mathrm{m}$ foram realizados por meio de uma câmara de micrótomo criostato (Cryocut-1800-Reichert-Jung), permanecendo a $-20^{\circ} \mathrm{C}$. Após o processo de corte, a amostra foi corada para determinar a atividade da Nicotinamida Adenina Dinucleotídeo Tetrazólio Redutase (NADH-TR) de acordo com a técnica de Pearse (1972) modificada por Dubowitz e Brooke (1984). A frequência e o tipo de fibra muscular foram avaliados e pelo programa de análise de imagem ImageJ 1.52a (National Institutes of Health, EUA). As fibras foram classificadas conforme proposto por Peter et al. (1972).

Para a obtenção do diâmetro dos tipos de fibras musculares foram analisados, em média, cinco campos microscópicos aleatórios por lâmina e 10 fibras por campo, pelo programa de análise de imagem ImageJ 1.52a (National Institutes of Health, EUA). Os diâmetros foram determinados medindo o menor diâmetro aparente através das fibras de forma irregular. 


\subsubsection{Quantificação de colágeno total e solúvel}

A análise de colágeno total e solúvel foi realizada com aproximadamente $4 \mathrm{~g}$ de amostra in natura do músculo Longissimus thoracis, em duplicata. Foram usadas amostras cruas totalmente trituradas em um processador (Modelo Mixer Walita RI1364 com microprocessador - Philips do Brasil LTDA, Divisão Walita - Varginha, Minas Gerais). A quantificação do colágeno foi realizada de acordo com a metodologia descrita por Cross et al. (1973).

A leitura das amostras foi feita em espectrofotômetro a $560 \mathrm{~nm}$ (Visível modelo V-M5 BEL). Para construção da curva padrão foi preparada solução stock de hidroxiprolina purificada (Sigma-Aldrich, St Louis, MO) com quatro concentrações conhecidas: 0,6; 1,2; 1,8; 2,4; 3,0 ug de hidroxiprolina/ml. O sobrenadante determinou a fração do colágeno solúvel, e o resíduo a fração de colágeno insolúvel, em mg/g. O colágeno total (mg de colágeno/g de carne), foi definido pela soma dos dois. A porcentagem de solubilidade foi calculada a partir da razão do colágeno presente na fração sobrenadante e o colágeno total.

\subsubsection{Análise Sensorial da carne}

Para avaliação sensorial da carne "in natura", as amostras do músculo Longissimus thoracis foram descongeladas sob refrigeração $\left(4^{\circ} \mathrm{C}\right)$ durante 24 horas, em seguida foram assadas em forno elétrico a $180^{\circ} \mathrm{C}$, até atingirem a temperatura interna no bife de $71^{\circ} \mathrm{C}$. (AMSA, 1995). Foram oferecidas quatro amostras para cada provador, nos tempos zero e 14 dias de maturação. As amostras foram codificadas com número de três dígitos e fornecidas de forma aleatória uma de cada vez aos provadores. As amostras foram disponibilizadas aos provadores, acompanhadas de pão de forma para remoção de sabor residual e água para lavagem do palato (FERREIRA et al., 2000).

Foi utilizado um teste sensorial, com painel não treinado de aceitação do consumidor (n = 100), tanto quantitativo quanto qualitativo, para as características sensoriais de aceitação global, sabor, maciez e suculência. Na análise quantitativa foi utilizada uma escala hedônica estruturada de nove pontos, variando de "desgostei extremamente" (nota 1) a "gostei extremamente" (nota - 9). Do mesmo modo, na análise qualitativa, uma escala hedônica de cinco pontos foi acoplada a um teste sob medida just-about-right, variando de "muito fraco, duro ou seco" (nota 1) a "muito forte, macio ou úmido" (nota 5) (WHEELER et al.,2015) (Anexo B).

\subsubsection{Delineamento experimental e análise estatística}

As análises estatísticas foram realizadas utilizando-se o procedimento MIXED do SAS $®$ 
(version 9.3). A significância foi declarada quando $\mathrm{P}<0,05$. Os dados obtidos foram avaliados por análise de variância, para verificar o efeito do grupo "raça" sobre as características avaliadas e abordagens uni e multivariadas, visando encontrar possíveis relações entre os valores dos grupos genéticos com as diferentes características avaliadas.

Para as características de desempenho e carcaça, os dados foram analisados considerando um delineamento inteiramente casualizado, foi incluído no modelo o efeito fixo de tratamento (grupos genéticos) e o peso vivo inicial como covariável. Para as análises de qualidade da carne (maciez e PPC) os dados foram analisados em parcelas subdivididas e com modelos mistos, considerando um arranjo fatorial $2 \times 3$ e para maciez e PPC, sendo os efeitos fixos: os grupos genéticos (Nelore e Nelore x Rubia Gallega), os tempos de maturação e suas interações. Para análise sensorial foi utilizado um delineamento em blocos, onde foi utilizado um modelo linear misto incluindo o efeito fixo de tratamento e o efeito aleatório de bloco (painelista).

Para realização dessas análises foram utilizados os procedimentos disponíveis no software SAS (version 9.3). Para avaliar o efeito do grupo genético sobre as características estudadas, os dados foram submetidos à ANOVA, sendo que quando houve efeito significativo, as médias foram comparadas utilizando-se o teste Tukey.

\subsection{RESULTADOS E DISCUSSÃO}

\subsubsection{Características de desempenho}

As características de desempenho produtivo, PF, GMD e EA, foram influenciadas pelo grupo genético $(\mathrm{P}<0,05)$. Bovinos RGN apresentaram maior taxa de crescimento, em relação ao N. No entanto, para PI e IMS, não foi observada diferença significativa entre os grupos $\mathrm{N} \mathrm{e}$ RGN (P > 0,05) (Tabela 2).

De acordo com os resultados obtidos para PI, observou-se peso semelhante entre os grupos genéticos no início do experimento. Ressalta-se que os animais eram jovens (11 meses de idade), pertencentes ao mesmo grupo contemporâneo e oriundos do mesmo sistema de produção e manejo. Os bovinos da raça $\mathrm{N}$ foram confinados com média de peso inicial de $298,62 \mathrm{~kg}$, enquanto os cruzados RGN com média de 279,38 kg.

Por outro lado, para PF, os bovinos do grupo RGN foram mais pesados que os animais $\mathrm{N}(\mathrm{P}<0,05)$, que apresentaram médias de peso final de $516,11 \mathrm{~kg}$ e $480,58 \mathrm{~kg}$, respectivamente. O maior peso final do grupo RGN pode ser consequência do maior GMD desses animais em 
relação aos animais do grupo $\mathrm{N}(\mathrm{P}<0,05)$. Portanto, os animais RGN ganharam em média 500 g a mais por dia, do que os animais $\mathrm{N}$ (Tabela 1).

O maior GMD e PF dos animais cruzados Rubia Gallega x Nelore pode ser explicado pelo fato de animais Bos taurus apresentarem elevadas taxas de crescimento e desempenho superior, em relação aos animais zebuínos (SANCHEZ et al., 2005b; TAVEIRA et al., 2014). Taveira et al. (2014), estudando touros Nelore e Rubia Gallega x Nelore, também relataram maior GMD e PF dos animais cruzados quando comparados ao Nelore puro, evidenciando a superioridade do genótipo RG, capaz de melhorar os aspectos produtivos relacionados ao ganho de peso.

Cruz et al. (2004) trabalhando com animais cruzados (Blonde d'Aquitaine - Ba, Cachim - CA, Limousin - L, Piemontês - P com Nelore - N e Nelore puro), confinados aos 12 meses de idade com PI médio de $215 \mathrm{~kg}$ por um período de aproximadamente 120 dias, verificaram valores médios de 468,25 kg para animais cruzados, e 400,30 para o $\mathrm{N}$, fato que converge com os resultados de PF e GMD obtidos neste estudo. Os resultados superiores obtidos para os bovinos cruzados são consequência do alto potencial genético de animais Bos taurus continental, que apresentam elevadas taxas de crescimento e desempenho superior, até mesmo em seus cruzamentos, sendo ainda mais evidente em animais com a característica de DM.

A EA também foi influenciada pelo grupo genético $(\mathrm{P}<0,05)$, mas não houve diferença significativa $(\mathrm{P}>0,05)$ quanto a IMS. Portanto, submetidos a mesma dieta, os animais cruzados apresentaram mesmo consumo e maior ganho de peso do que os animais N. Dessa forma, sugere-se que raças europeias demonstram melhor capacidade de utilização do componentes nutricionais da dieta. Esse resultado pode ser explicado pela influência da dupla musculatura presente nos animais RGN. De acordo com Arthur (1995), animais de raça europeia DM, como a RG usado no cruzamento em questão, apresentam menor consumo e melhor eficiência alimentar com maior ganho de peso e consequentemente maior porcentagem de corte cárneos.

Os resultados de desempenho produtivo, no presente estudo, estão de acordo com as observações feitas por Euclides filho (1997) sobre animais F1, em que animais de raças europeias cruzados com Nelore apresentaram superioridade produtiva de, aproximadamente, $15 \%$ em relação aos bovinos $\mathrm{N}$ puros.

Diante disso, o cruzamento entre raças europeias (Bos taurus) com uma raça adaptada ao clima tropical (Bos indicus), como a Nelore, possibilita a geração de animais superiores em aspectos produtivos (ganho de peso, musculosidade e precocidade). Sugere-se assim, que o cruzamento RGN é capaz de acelerar e aumentar a produção de carne. 
Tabela 2: Características de desempenho de bovinos Nelore e Rubia Gallega x Nelore confinados

\begin{tabular}{ccccc}
\hline Característica $^{1}$ & $\mathrm{~N}^{2}$ & $\mathrm{RGN}^{2}$ & $\mathrm{EPM}^{3}$ & $P$ \\
\hline PI (kg) & 298,63 & 279,38 & 7,391 & 0,0754 \\
PF (kg) & 480,58 & 516,11 & 5,453 & $<0,0001$ \\
GMD (kg) & 1,48 & 1,75 & 0,093 & 0,0012 \\
EA & 0,18 & 0,22 & 0,003 & $<0,0001$ \\
IMS (\%) & 2,21 & 2,23 & 0,040 & 0,7582 \\
\hline
\end{tabular}

1PI: peso inicial (11 meses); PF: peso final (15 meses); GMD: ganho de peso médio diário; EA: eficiência alimentar; IMS: ingestão de matéria seca.

${ }^{2} \mathrm{~N}$ : Nelore; RGN: cruzamento Rubia Gallega x Nelore.

${ }^{3}$ EPM: erro padrão da média.

\subsubsection{Ultrassom e Características de carcaça}

As características de carcaça, AOLU, EGSU e EGPU, avaliadas por ultrassom, foram influenciadas pelos grupos genéticos $(\mathrm{P}<0,05$; Tabela 3$)$. Foram observadas associações lineares positivas (P < 0,05) da EGSU (Figura 1) e da EGPU (Figura 2), com a evolução do tempo de confinamento.

Animais RGN (37,86 $\left.\mathrm{cm}^{2}\right)$ apresentaram maiores AOLU, comparados a N $\left(36,20 \mathrm{~cm}^{2}\right)$. Como a medida de AOLU de ultrassom é positivamente correlacionada com o peso vivo e o ganho de peso (KOOHMARAIE et al., 2003), pode-se inferir que os maiores valores dessa característica em RGN foram associados aos maiores pesos ao final do confinamento dos animais pertencentes à raça. Vários autores também relataram este resultado, uma vez que animais taurinos apresentam maior capacidade de crescimento muscular em relação aos zebuínos (MORALES et al., 2002).

Para as características de EGSU e EGPU foi observada interação entre grupo genético e tempo de confinamento $(\mathrm{P}<0,05)$. Sugere-se que a deposição de gordura foi mais rápida e maior em bovinos N, comparado a RGN. Esse resultado é explicado devido à raça Rubia Gallega ser classificada como alta produtora de carne, porém, com maturidade tardia, apresentando elevada taxa de crescimento e baixa predisposição genética para a deposição de gordura (ALBERTÍ et al., 2005; MONSERRAT \& SÁNCHEZ, 2000).

Esses resultados estão de acordo com estudos envolvendo análises moleculares realizados por McPherron e Lee (1997), que testaram ratos e demonstraram com o bloqueio da atividade do gene $M S T N$ a ocorrência de aumento significativo na massa muscular dos animais, tendo esses a quantidade de gordura reduzida. 
Arthur (1995) e Wheeler et al. (2001) descreveram, que animais com DM apresentam características de carcaça superiores aos normais devido principalmente à hipertrofia muscular e consequente menor proporção de gordura.

Portanto, a combinação entre raças com maior musculosidade, neste estudo, representada pela raça Rubia Gallega, com outra raça de menor porte muscular, como a Nelore, pode propiciar a geração de animais com carcaças mais pesadas e com cobertura de gordura favorável (3 mm).

Tabela 3: Característica de ultrassom de carcaça de bovinos Nelore e Rubia Gallega x Nelore confinados

\begin{tabular}{|c|c|c|c|c|}
\hline \multirow{2}{*}{\multicolumn{2}{|c|}{ Efeito fixo }} & \multicolumn{3}{|c|}{ Característica $^{1}$} \\
\hline & & \multicolumn{3}{|c|}{ Ultrassom de carcaça } \\
\hline Tratamento $^{2}$ & Tempo $^{3}$ & $\operatorname{AOLU}\left(\mathrm{cm}^{2}\right)$ & EGSU (mm) & EGPU (mm) \\
\hline \multicolumn{5}{|c|}{ Efeito principal } \\
\hline $\mathrm{N}$ & & 36,20 & 5,36 & 5,21 \\
\hline \multirow[t]{7}{*}{$\mathrm{R}$} & & 37,86 & 3,61 & 3,01 \\
\hline & 0 & $31,56^{\mathrm{a}}$ & $2,88^{\mathrm{a}}$ & $2,36^{\mathrm{a}}$ \\
\hline & 21 & $36,22^{b}$ & $3,46^{\mathrm{b}}$ & $3,23^{b}$ \\
\hline & 43 & $38,29^{b}$ & $4,20^{\mathrm{b}}$ & $3,76^{\mathrm{b}}$ \\
\hline & 70 & $37,01^{\mathrm{b}, \mathrm{c}}$ & $5,06^{\mathrm{c}}$ & $4,52^{c}$ \\
\hline & 100 & $38,12^{\mathrm{c}}$ & $5,11^{\mathrm{d}}$ & $4,94^{\mathrm{c}}$ \\
\hline & 120 & $40,98^{\mathrm{d}}$ & $6,21^{\mathrm{e}}$ & $5,84^{\mathrm{d}}$ \\
\hline \multicolumn{5}{|c|}{ Média } \\
\hline Média & & 37,03 & 4,49 & 4,12 \\
\hline Erro Padrão & & 0,359 & 0,131 & 0,146 \\
\hline \multicolumn{5}{|c|}{ Probabilidade estatística } \\
\hline Tratamento & & 0,0027 & $<0,0001$ & $<0,0001$ \\
\hline Tempo & & $<0,0001$ & $<0,0001$ & $<0,0001$ \\
\hline Tratamento*Tempo & & 0,1832 & 0,0017 & 0,0002 \\
\hline
\end{tabular}

${ }^{1}$ AOLU: área do músculo Longissimus thoracis; EGSU: espessura de gordura sobre o músculo Longissimus thoracis; EGPU: espessura de gordura sobre o músculo Bíceps femoris.

${ }^{2}$ Grupo Genético: N: Nelore; RGN: cruzamento Rubia Gallega x Nelore.

${ }^{3}$ Ultrassonografia nos dias de confinamento zero, 21, 43, 70, 100 e 120:

a, b, c Médias na mesma coluna seguidas por letras diferentes indicam que houve diferença entre si $(P<0,05)$. 
Figura 1. Espessura de gordura média sobre o músculo Longissimus thoracis, avaliada por ultrassom, de bovinos Nelore e cruzados Rubia Gallega x Nelore, em função dos dias de confinamento.

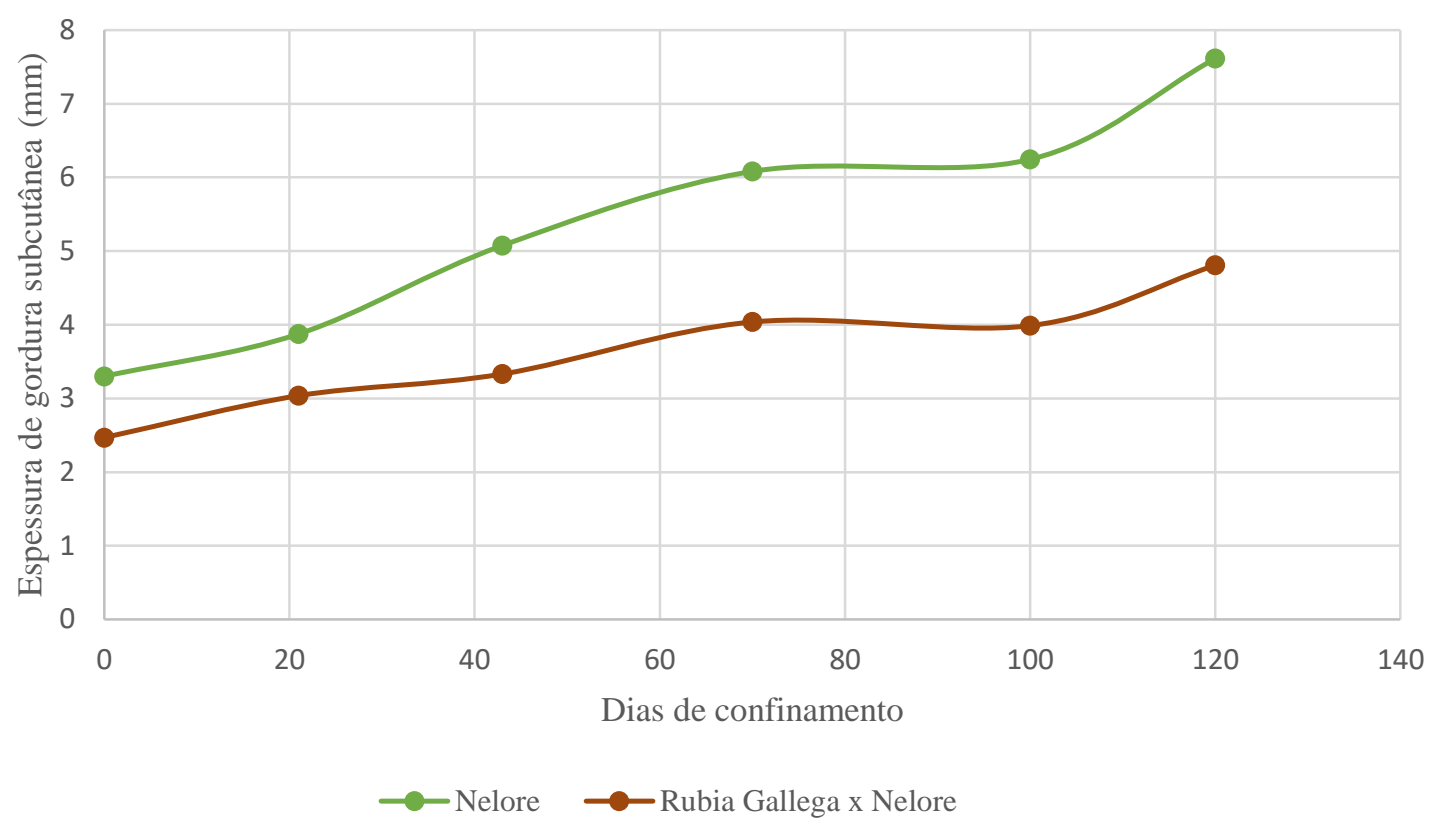

Fonte: Própria autoria

Figura 2. Espessura de gordura média sobre o músculo biceps femoris, avaliada por ultrassom, de bovinos Nelore e cruzados Rubia Gallega x Nelore, em função dos dias de confinamento.

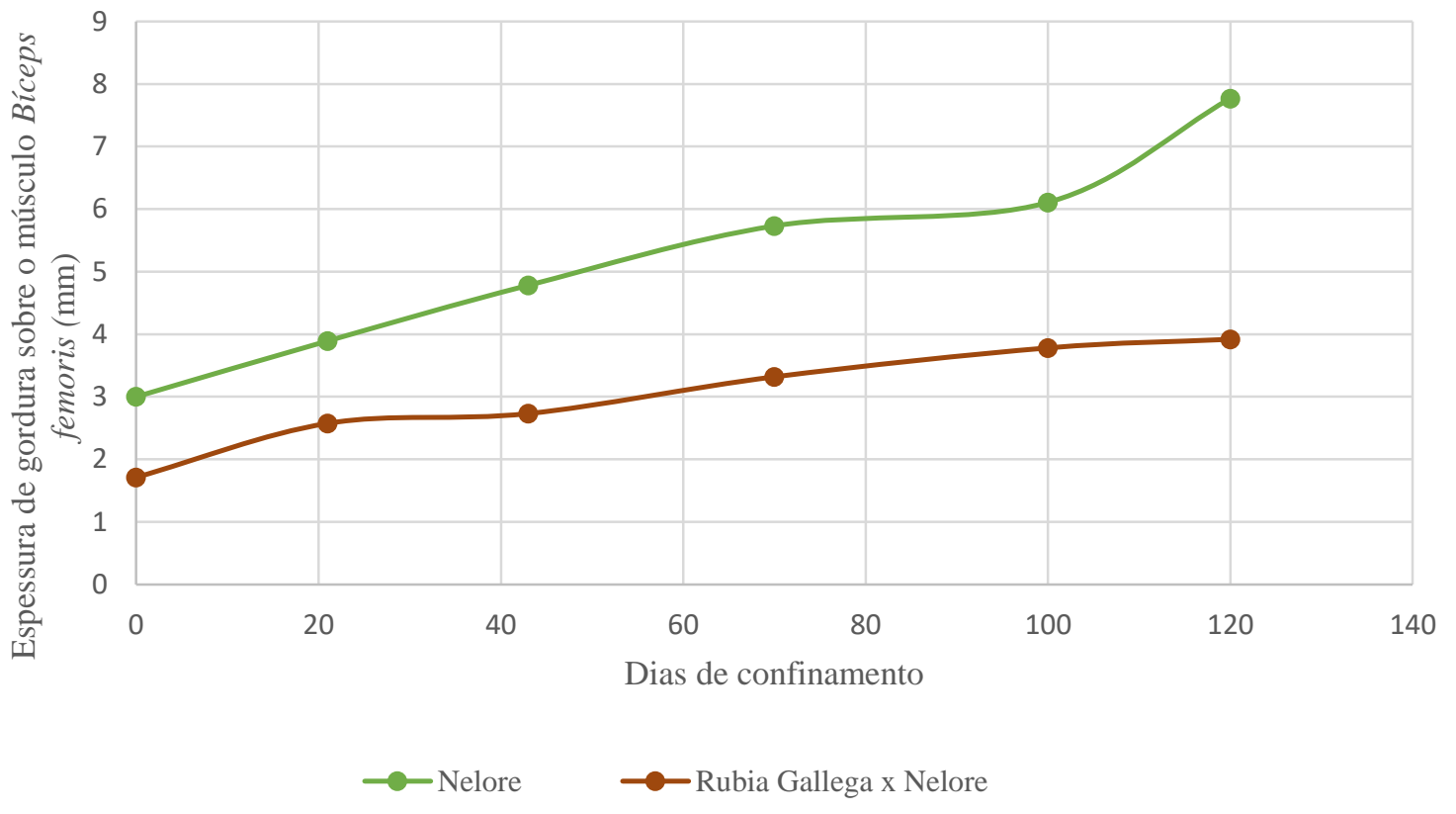

Fonte: Própria autoria 
As características de carcaça também foram avaliadas durante o abate (PCQ e RC) e na desossa (AOL, EGS e pH), os resultados são apresentados na Tabela 4. Houve diferença entre os grupos genéticos para PCQ e RC $(\mathrm{P}<0,05)$. Para ambas as características, animais do grupo RGN apresentaram valores superiores ao grupo N, propiciando carcaças mais pesadas e com maior rendimento. Carcaças de RGN tiveram 5,5\% (PCQ) e 1,3\% (RC) mais pesadas que grupo N. Este resultado era esperado, devido o grupo RGN apresentar a característica de DM. De acordo com Fiems (2012), os animais dupla musculatura podem ter RC 11\% superior quando comparados aos animais normais, devido ao maior teor de carne magra na carcaça.

Cabe destacar que o PCQ dos animais do grupo RGN do presente estudo foram aproximadamente $15 \mathrm{~kg}$ superiores que os bovinos $\mathrm{N}$, concordando com os dados de Wheeler et al. (2005) que relataram as raças continentais europeias como maiores produtoras de carne, com ganho de 10 a 20 kg de PCQ, em relação as raças zebuínas e britânicas.

Para a característica de RC, bovinos RGN tiveram 57,46\%, portanto, superior a $\mathrm{N}$ $(56,13 \%)$. No estudo, o resultado de RC foi maior que o valor obtido por Silva (2011), de $54,96 \%$. O PCQ e RC estão diretamente relacionados ao maior ganho de peso e maior peso final do grupo genético RGN, em comparação com N. Em consenso, segundo Oliete et al. (2006), RG possui maior taxa de crescimento, apresentando alto rendimento de carcaça e cortes comerciais.

Os resultados obtidos para as características de carcaça foram similares àqueles observados por Sánchez et al. (2005a), que trabalharam com bovinos Rubia Gallega, criados a pasto com suplementação e abatidos com aproximadamente 22 meses de idade, e encontraram um incremento de aproximadamente 2,69 \% no rendimento de carcaça dos animais cruzados, comprovando a maior musculosidade da raça RG em relação à N. Além disso, Palhari (2014) constatou, ao avaliar novilhos Nelore e F1 Rubia Gallega x Nelore, suplementados com cromo, maiores médias de PCQ para animais RGN $(262,1 \mathrm{~kg})$, em relação à N $(247,6$ kg).

A AOL foi influenciada pelo grupo genético $(\mathrm{P}<0,05)$, com médias superiores, de 90,19 $\mathrm{cm}^{2}$, para RGN e $76,44 \mathrm{~cm}^{2}$ para $\mathrm{N}$, demonstrando o efeito positivo do cruzamento no aumento da musculosidade, como já era esperado, devido ao maior potencial de deposição de musculatura dos animais RG. Vale ressaltar, que a característica de AOL está diretamente relacionada à proporção de cortes na carcaça, evidenciando uma maior produção de músculo para animais cruzados.

Em estudo realizado por Suguisawa et al. (2006) com animais Simental, Angus cruzados com Nelore e Nelore puro, também observou-se maior AOL para animais Simental e Angus, 
cruzados com Nelore, quando comparados aos bovinos Nelore puros. Lopes et al. (2012) mencionaram que animais Bos taurus apresentam maior taxa de crescimento tendo como consequência apresentar maior AOL que Bos indicus.

A EGS foi maior $(\mathrm{P}<0,05)$ no grupo $\mathrm{N}(5,85 \mathrm{~mm})$ em relação a RGN $(3,07 \mathrm{~mm})$. Esse resultado era esperado, visto que animais RG apresentam baixa deposição de gordura e maior deposição de músculo (OLIETE et al., 2006). De acordo com Salviano-Teixeira et al. (2006), animais com características de DM podem apresentar 3\% menos gordura e 8\% mais músculos que os animais normais. Também, Silva (2011) avaliou bovinos RGN com 24 meses de idade e obteve valores baixos de EGS (1,59 mm), inferindo que animais RGN apresentam deposição de gordura inferior.

A EGS é importante, pois atua como um isolante térmico na carcaça e influencia a maciez, pois reduz a velocidade de queda da temperatura e do $\mathrm{pH}$ durante o resfriamento pós morte, diminuindo a possibilidade de ocorrer o encurtamento pelo frio das fibras musculares (SAÑUDO et al., 2000). Enfatiza-se que as médias de EGS, independente do biotipo, atendem à espessura mínima de $3 \mathrm{~mm}$ exigida pelos frigoríficos, a fim de proteger o músculo contra $\mathrm{o}$ frio e evitar perdas na qualidade da carne (LUCHIARI FILHO, 2000). De acordo Luchiari Filho (2000), maiores valores de AOL e menores de EGS são indicativos de maior rendimento muscular, maior proporção de cortes de carne utilizáveis e menor proporção de gordura corporal na carcaça, característico de carcaças de animais DM.

Não houve diferença entre os grupos genéticos $(\mathrm{P}>0,05)$ para o $\mathrm{pH}$ do músculo Longissimus thoracis 24 horas post mortem. Bovinos $\mathrm{N}$ apresentaram média de $\mathrm{pH}$ de 5,63, enquanto RGN de 5,68 (Tabela 2). Esses valores estão dentro da faixa normal de 5,5 a 5,79 para a carne bovina, de acordo com Prieto et al. (2018). Os valores observados no presente estudo foram semelhantes aos relatados por Bispo et al. ( 2010) e Oliete et al. (2006) em RG. É importante salientar que os animais não permaneceram em jejum prolongado, não foram transportados por longa distância e não permaneceram por longo período de tempo no curral de espera. De acordo com Ferguson et al. (2008), quando os bovinos são acometidos por estresse pré-abate, a reserva de glicogênio dos músculos desses animais pode ser parcial ou totalmente esgotado impactando no $\mathrm{pH}$ final e consequentemente afetando a qualidade da carne.

Assim, o cruzamento realizado entre bovinos continentais europeus e zebuínos pode ser realizado a fim de combinar as qualidades de rusticidade da raça Nelore com a característica de especialidade em produção de carne da raça Rubia Gallega. Portanto, o cruzamento RGN promove um incremento na quantidade de cortes cárneos dos animais. 
Tabela 4: Características da carcaça e carne de bovinos Nelore e Rubia Gallega x Nelore confinados

\begin{tabular}{lcccc}
\hline Característica $^{1}$ & $\mathrm{~N}^{2}$ & $\mathrm{RGN}^{2}$ & $\mathrm{EPM}^{3}$ & $P$ \\
\hline PCQ $(\mathrm{kg})$ & 270,06 & 296,32 & 3,806 & $<0,0001$ \\
RC $(\%)$ & 56,17 & 57,46 & 0,385 & 0,0332 \\
AOL $\left(\mathrm{cm}^{2}\right)$ & 76,44 & 90,19 & 7,263 & $<0,0001$ \\
EGS $(\mathrm{mm})$ & 5,86 & 3,07 & 0,728 & $<0,0001$ \\
pH final & 5,64 & 5,69 & 0,039 & 0,4360 \\
\hline
\end{tabular}

PCQ: peso de carcaça quente; RC: rendimento de carcaça; AOL: área de olho de lombo; EGS: espessura de gordura subcutânea.

${ }^{2} \mathrm{~N}$ : Nelore; RGN: cruzamento Rubia Gallega x Nelore.

${ }^{3}$ EPM: erro padrão da média.

\subsubsection{Características de qualidade da carne}

As características de qualidade, FC, cor, PPC e LT, foram influenciadas pelos grupos genéticos $(\mathrm{P}<0,05$; Tabela 5 e 6$)$. A força de cisalhamento e a cor também foram influenciadas pelo período de maturação $(\mathrm{P}<0,05)$, independente do grupo genético. Para as demais características de qualidade da carne, MARB, teor de colágeno, solubilidade de colágeno, número de fibras e diâmetro de fibras, não houve diferença entre os tratamentos $(\mathrm{P}>0,05$; Tabela 6). Não houve interação $(P>0,05)$ entre grupo genético e dias de maturação para as características de qualidade de carne.

A carne dos animais RGN apresentou menor FC (53,05 N), perdas por cocção $(27,78 \%)$, $L^{*}(42,21), a^{*}(17,16)$ e b* $(15,40)$, quando comparada à $\mathrm{N}(58,84 \mathrm{~N}, 29,61 \%, 43,22,17,61$, 16,09 , respectivamente).

Os resultados de FC indicam que ambos os grupos genéticos apresentam carne dura, pois de acordo com o Departamento de Agricultura dos Estados Unidos (USDA, 2011), o valor da força de cisalhamento para a carne ser considerada macia deveria ser menor ou igual a 43,15 N. As maiores médias de FC, verificadas em $\mathrm{N}$ podem ser explicadas pelo genótipo da raça, limitada a taxa de maturação e a atividade de enzimas proteolíticas. Segundo Shackelford et al. (1994), aproximadamente $65 \%$ da variação na maciez da carne bovina está relacionada a fatores genéticos e apenas $35 \%$ devido a fatores ambientais. Vários estudos indicaram que a carne de Bos indicus é mais dura, devido ao menor conteúdo de gordura intramuscular e maior quantidade de tecido conjuntivo quando comparada à carne bovina de Bos taurus (BELEW et al., 2003). Além disso, Koohmaraie (1994), relatou que Bos indicus apresentam maior atividade de calpastatina quando comparados aos Bos taurus. Essa atividade elevada de calpastatina em bovinos Bos indicus diminui a proteólise post mortem, afetando negativamente a 
maciez. Existem diversos fatores que associam o genótipo Bos indicus com a redução da maciez da carne, o mais importante é ação proteolítica, como a maior atividade de calpastatina, inibidora natural das calpaínas. Ainda, Sazili et al. (2004) relataram que não houve relação entre a taxa de crescimento e a força de cisalhamento, ou ainda, entre os níveis de m e $\mu$-calpaínas e a força de cisalhamento, em animais com altas taxas de crescimento, embora os valores de força fossem positivamente relacionados com a intensidade de calpastatina até 24 horas pós-morte.

Sanchez et al. (2005a), ao estudarem animais cruzados Rubia Gallega x Nelore relataram média de 52,76 $\mathrm{N}$ para FC, valor próximo ao encontrado nesse trabalho $(53,05 \mathrm{~N})$. Nossos resultados sugerem que a carne bovina de animais mestiços apresenta menor FC, sendo classificada como mais macia do que a carne bovina de Bos indicus.

A maturação também influenciou a maciez da carne $(\mathrm{P}<0,05)$, promovendo redução de, aproximadamente, $40 \%$ na FC do dia zero ao dia 21 de maturação, em ambos os grupos genéticos. A média de FC de carnes não maturadas foi $76,79 \mathrm{~N}$, já as carnes que foram maturadas por 14 dias tiveram FC de 46,87 N, não havendo diferença significativa na maciez entre os dias 14 e 21 de maturação $(46,29 \mathrm{~N})$. Tais resultados sugerem que o músculo Longissimus thoracis deve ser maturado por pelo menos 14 dias, independente do grupo genético estudado, para que atinja valores de maciez aceitáveis. De acordo com Koohmaraie et al. (2002), até o 14ํ dia post mortem, o processo de maturação é mais intenso, causando maior degradação proteolítica das proteínas, enfraquecimento das miofibrilas, e maior comprimento de sarcômero, assim promovendo o amaciamento da carne.

Puga et al. (1999), relataram aumento de maciez na carne de $20 \%$ com a maturação por 14 dias. Eilers et al. (1996), ao avaliarem raças e cruzamentos bovinos, incluindo Bos taurus e Bos indicus, observaram que o maior amaciamento da carne bovina também ocorre nos primeiros 12 dias de maturação. Desta forma, é possível indicar no presente estudo que não há necessidade de maturação da carne por 21 dias, visto que não houve diferença entre 14 e 21 dias de maturação.

As PPC foram influenciadas pelos grupos genéticos $(\mathrm{P}<0,05)$, a carne de RGN apresentou menor PCC $(27,78 \%)$ em comparação a N (29,61\%). Como menores perdas de peso por cocção indicam aumento da capacidade de retenção de água da carne, os resultados obtidos neste estudo permitem inferir que a carne dos animais cruzados possui maior capacidade de retenção de água e essa menor perda por cocção pode afetar diretamente na suculência da carne. Silva (2011) e Sanchez et al. (2005b) encontraram valores de PPC de 25,57\% e 30,41\%, respectivamente, para animais cruzados Rubia Gallega x Nelore, semelhantes aos valores 
encontrados neste estudo. Além disso, Chambaz et al. (2003) ao avaliarem diferentes raças bovinas, observaram menor PPC em animais Limousin, Charolês e Simental, quando comparados aos bovinos Angus. Diante disso, sugere-se que a carne de animais Bos taurus com predisposição a dupla musculatura retém mais água entre seus feixes musculares. Ressalta-se que os valores encontrados no estudo são aceitáveis, pois segundo Muchenje et al. (2009) porcentagens de PPC entre 13,1\% e 34,54\% são considerados adequadas para a carne bovina.

Em relação à coloração da carne, os valores encontrados em ambos os grupos genéticos são superiores a variação considerada normal para espécie bovina de L* (luminosidade), intervalo de 31,31 a 41,29, compreendem a variação ideal para a* (intensidade de vermelho), de 9,40 a 18,74 e superiores ao intervalo ideal para b* (intensidade de amarelo), de 3,36 a 10,40, relatadas por Zorzi el al. (2013) e Yüksei at al. (2012).

No entanto, Pateiro et al. (2017), ao avaliarem animais cruzados Holandês x Rubia Gallega, encontraram 45,64 para $L^{*}$ e 14,76 para $b^{*}$, indicando que o valor é característico da raça $\mathrm{RG}$, usada no cruzamento. Bovinos $\mathrm{N}$ apresentaram carnes levemente mais amareladas $(16,09)$ do que os bovinos RGN $(15,40)$, essa diferença observada para $b^{*}$, pode estar associada tanto ao baixo conteúdo de gordura intramuscular, quanto à maior proporção de fibras glicolíticas (fibras brancas), relatadas em animais DM (FIEMS, 2012). Também sugere-se que este resultado possa ser devido a maior concentração de lipídeos totais no grupo N (2,03\%) em comparação ao RGN (1,43\%; dados apresentados a seguir). Vale ressaltar que o valor médio do pH do músculo Longissimus thoracis, após 24 horas post mortem foi de 5,63 e 5,68, para os grupos N e RGN, respectivamente, considerados normais $(5,5$ e 5,79) para a carne bovina, não refletindo em alterações na cor (PRIETO et al., 2018).

Os parâmetros de cor foram influenciados pelo período de maturação $(\mathrm{P} \leq 0,05)$. As carnes maturadas por 14 e 21 dias apresentaram maiores valores de $L^{*}, a^{*}$ e b*, em relação àquelas não maturadas $(P \leq 0,05)$. Stanišić et al. (2012) também observou aumento nos valores de $a^{*}$ e b* em carnes bovinas, ao longo do tempo de maturação. O aumento de $\mathrm{L}^{*}$ em carnes maturadas também foi observado por Oliveira et al. (2011) e Colle et al. (2015). O aumento no valor de a* pode estar relacionado a perda de atividade respiratória das mitocôndrias durante a maturação, que faz com que haja mais oxigênio disponível na superfície do músculo, e, portanto, pode ser utilizado para formar oximioglobina (O'KEFFE \& HOOD, 1982). 
Tabela 5: Características de qualidade da carne de bovinos Nelore e Rubia Gallega x Nelore confinados

\begin{tabular}{|c|c|c|c|c|c|c|}
\hline \multicolumn{2}{|l|}{ Efeito fixo } & \multicolumn{5}{|c|}{ Característica $^{1}$} \\
\hline Tratamento $^{2}$ & Tempo $^{3}$ & $\mathbf{F C}(\mathbf{N})$ & $\operatorname{PPC}(\%)$ & $\mathbf{L}^{*}$ & $\mathbf{a}$ & $\mathbf{b}$ \\
\hline \multicolumn{7}{|c|}{ Efeito principal } \\
\hline $\mathrm{N}$ & & 58,84 & 29,61 & 43,22 & 17,61 & 16,09 \\
\hline \multirow[t]{5}{*}{$\mathrm{R}$} & & 53,05 & 27,78 & 42,21 & 17,16 & 15,40 \\
\hline & 0 & $76,79^{\mathrm{a}}$ & 29,90 & $40,60^{\mathrm{b}}$ & $17,02^{b}$ & $14,76^{\mathrm{a}}$ \\
\hline & 7 & $53,84^{\mathrm{b}}$ & 28,12 & $43,33^{\mathrm{a}}$ & $17,20^{\mathrm{a}, \mathrm{b}}$ & $15,68^{\mathrm{a}, \mathrm{b}}$ \\
\hline & 14 & $46,87^{\mathrm{c}}$ & 28,23 & $43,66^{\mathrm{a}}$ & $17,80^{\mathrm{a}}$ & $16,39^{\mathrm{b}}$ \\
\hline & 21 & $46,29^{c}$ & 28,55 & $43,27^{\mathrm{a}}$ & $17,54^{\mathrm{a}}$ & $16,15^{\mathrm{c}}$ \\
\hline \multicolumn{7}{|c|}{ Média } \\
\hline Média & & 56,00 & 28,70 & 42,72 & 17,39 & 15,744 \\
\hline Erro Padrão & & 0,171 & 0,353 & 0,237 & 0,110 & 0,128 \\
\hline \multicolumn{7}{|c|}{ Probabilidade estatística } \\
\hline Tratamento & & 0,0251 & 0,0043 & 0,0157 & 0,0358 & 0,0028 \\
\hline Tempo & & $<0,0001$ & 0,1713 & $<0,0001$ & 0,0515 & $<0,0001$ \\
\hline Tratamento*Tempo & & 0,5731 & 0,2636 & 0,2392 & 0,4297 & 0,4817 \\
\hline
\end{tabular}

${ }^{1} \mathrm{FC}$ : força de cisalhamento; PPC: perdas por cocção; L*: luminosidade; $\mathrm{a}^{*}$ : intensidade de vermelho; $\mathrm{b}^{*}$ : intensidade de amarelo.

${ }^{2}$ Grupo Genético: N: Nelore; RGN: cruzamento Rubia Gallega x Nelore.

${ }^{3}$ Dia zero, 7,14 e 21: Período de maturação da carne em câmara de resfriamento a $4{ }^{\circ} \mathrm{C}$.

a, b, c Médias na mesma coluna seguidas por letras diferentes indicam que houve diferença entre si $(P<0,05)$.

A concentração de lipídios totais da carne foi alterada pelos grupos genéticos $(\mathrm{P}<0,05)$. Bovinos $\mathrm{N}$ apresentaram maior deposição lipídica no músculo (2,03\%), quando comparados aos RGN (1,43\%). A quantidade de lipídios presente na carne de bovinos varia entre $4-15 \%$ e é influenciada principalmente pelo grupo genético (SCOLLAN et al., 2006). O resultado obtido neste estudo era esperado para os animais cruzados, visto que raças continentais, como a Rubia Gallega, são caracterizadas pelo baixo teor de gordura corporal, devido as maiores taxas de crescimento muscular (MONSERRAT \& SÁNCHEZ, 2000). Segundo, Wiener et al. (2009), bovinos de dupla musculatura apresentam menor taxa de crescimento dos adipócitos no tecido muscular quando comparados com bovinos sem a presença de DM. Ainda assim, os resultados 
de composição lipídica indicam que ambos os grupos genéticos apresentaram baixa porcentagem de lipídios na carne (menor que 4\%), de acordo com Scollan et al. (2006), resultando em alimento mais favorável para saúde, que atende consumidores que estão em busca de uma carne com maior qualidade nutricional.

Os valores de lipídeos totais no presente estudo estão próximos aos encontrados por Pateiro et al. (2017), para bovinos cruzados Holandês x Limousin e Holandês x Rubia Gallega, de $1,56 \%$ e $1,63 \%$, respectivamente. Moreno et al. (2006), em estudos realizados com animais da raça Rubia Gallega, comparando a idade ao desmame antes do abate, observaram valores inferiores aos do presente estudos, de $0,70 \%$ de gordura na composição química do músculo Longissimus thoracis de animais RG.

Não foram observadas diferenças entre os grupos genéticos para o escore de marmorização $(\mathrm{P}>0,05)$. Bovinos $\mathrm{N}$ apresentaram marmorização em média de 4,67, enquanto RGN tiveram escore de 4,45. Portanto, ambos os grupos apresentaram baixa deposição de gordura intramuscular. $\mathrm{O}$ conteúdo da gordura intramuscular relaciona-se intrinsecamente à raça (FEITOSA et al., 2017). Animais de raças zebuínas e europeias continentais apresentam baixa predisposição genética para deposição de gordura intramuscular quando comparados com Bos taurus (raças de origem britânica) (DE SMET, RAES e DEMEYER, 2004), desta forma, tal resultado era esperado. Além disso, os animais foram abatidos jovens, não havendo deposição de gordura intramuscular, que segundo Sainz \& Hasting (2000) é a última a ser depositada.

A baixa pontuação na marmorização obtida para RGN também foi observada por Wiener et al. (2009) e Aldai et al. (2007) em bovinos dupla musculatura, que são caracterizados pelo baixo teor de gordura intramuscular, devido adipócitos menores em marmorização, quando comparados com bovinos sem a presença de dupla musculatura.

$\mathrm{O}$ teor de colágeno na carne não foi influenciado pelos grupos genéticos $(\mathrm{P}>0,05)$. Sabe-se que, em animais jovens, a influência do tecido conjuntivo é sutil, prevalecendo o efeito de outros fatores na maciez da carne, como a intensidade da proteólise e o grau de contração do tecido muscular (LAWRENCE et al., 2001). Esse resultado provavelmente ocorreu devido os animais terem sido abatidos jovens (15 meses) e com a mesma idade, não havendo diferença entre a quantidade total de colágeno na carne do grupo N (3,56 mg) e RGN (3,81 mg). Ressaltase que animais mais velhos tendem a apresentar redução na maciez da carne, com diminuição do teor de colágeno solúvel, pelo o aumento da estabilidade térmica do colágeno, resultante da formação de pontes cruzadas. Enquanto animais mais jovens, apresentam ligações cruzadas 
intermoleculares presentes no colágeno mais instáveis ao calor, predominando maior relação colágeno solúvel: insolúvel. (LAWRENCE et al., 2001).

Restle et al. (1997), trabalhando com animais Hereford (H) e Nelore, verificaram 3,91 mg colágeno por grama de músculo em animais $5 / 8 \mathrm{H}$ e $3 / 8 \mathrm{~N}$, semelhante aos valores obtidos no presente estudo. Potanto neste trabalho, a maior maciez da carne de RGN foi influenciada por outros fatores, como a intesidade da atividade das enzimas proteolíticas e o genótipo da raça, sugerindo que a maciez, em animais jovens, não apresenta influência do colágeno.

O mesmo comportamento ocorreu para a solubilidade do colágeno, a qual também não diferiu entre os grupos genéticos $(\mathrm{P}>0,05)$. Esses resultados para solubilidade do colágeno eram esperados, já que os animais eram jovens e não apresentaram variação na idade. Em animais jovens a síntese de colágeno novo é mais rápida e existem poucas ligações cruzadas, assim, este é facilmente solubilizado a cocção (BAILEY, 1985). Heinemann et al. (2003), trabalharam com animais Nelore e cruzados Nelore x Limousin, com diferentes idades (18 e 24 meses) e concluíram que o teor de colágeno de animais cruzados foi, em média, ligeiramente inferior aos animais Nelore. A solubilidade do colágeno foi significativamente maior em animais mais jovens e mais leves. Assim, sugere-se que o uso de animais com idades diferentes poderia resultar em diferenças no teor total e na solubilidade do colágeno entre os grupos genéticos estudados.

Em relação ao número de fibras musculares, não foi observada diferença entre os grupos genéticos $(\mathrm{P}>0,05)$. A frequência das fibras SO (fibra oxidativa de contração lenta), FOG (fibra glicolítica-oxidativa de contração rápida) e FG (fibra glicolítica de contração rápida) (Figura 3) foram semelhantes entre os grupos genéticos. A multiplicação do número de fibras musculares (hiperplasia) ocorre na fase fetal e o número de fibras está completo ao nascimento do animal (UYTTERHAEGEN et al., 1994). A quantidade de cada tipo de fibra está relacionada com a seleção genética para o desenvolvimento muscular. Além disso, a idade também é um fator que pode afetar a frequência dos tipos de fibras musculares (HAWKINS; MOODY; KEMP, 1985). À medida que ocorre o avanço da idade pode haver modulação de fibras musculares, fibras SO podem ser moduladas à FG (LYNCH \& KOOPMAN, 2019). De acordo com Boccard (1982) e Rehfeldt et al. (2004), bovinos DM possuem maior número de fibras musculares, com maior proporção de fibras glicolíticas pois estas fibras apresentam maior diâmetro que fibras musculares oxidativas. Como os animais do estudo eram jovens, sugere-se que com o avançar da idade, RGN apresente maior frequência de fibra FG devido à constituição genética de animais RG. Wegner et al. (2000), ao avaliarem características das fibras 
musculares em bovinos Belgian Blue, observaram o dobro de fibras no músculo Semitendinosus, com maior proporção de fibras FG, comparado as outras três raças estudadas que não possuíam DM (Angus, Galloway e Holstein Friesian).

Os grupos genéticos apresentaram diâmetro de fibras musculares semelhantes $(\mathrm{P}>$ 0,05). Comparando-se o tamanho e o tipo da fibra, foi observado que as fibras SO foram as menores, o tipo FG o maior e o tipo FOG tem tamanho intermediário para ambos os grupos genéticos, de acordo com Brandstetter et al. (1996). Raças com fenótipo DM possuem ampliação individual das fibras (hipertrofia), quando comparadas àquelas que não detêm essa característica e isso contribui para maior maciez da carne (GAGNIERE et al., 1997). No entanto, no presente estudo animais RGN não apresentaram fibras de maior diâmetro comparado aos animais do grupo $\mathrm{N}$ (tabela 6), o que pode ser devido aos animais terem sido abatidos muito jovens. Portanto esse fator não influenciou a maciez apresentada pelo grupo RGN.

Os resultados do estudo corroboram com aqueles encontrados por Ozawa et al. (2000), que constataram semelhança no diâmetro das fibras e entre os tipos de fibras musculares em animais cruzados. Entratanto, Wegner et al. (2000) avaliaram bovinos Belgian Blue e constatou-se um aumento linear de 9 a 10 vezes na dimensão das fibras musculares, desde o nascimento até os 24 meses, indicando que a hipertrofia determinou o crescimento muscular pós-natal desses animais.

Portanto, sugere-se que uma nutrição, mais proteica, na fase de recria, a fim de aproveitar o pico da curva de crescimento fisiológico animal, para obter maior incremento muscular (hipertrofia). Aliado a isso, um desafio nutricional mais intenso (dieta com maior densidade energética), durante a fase de confinamento, e abate de animais com idade mais avançada (20-22 mêses) poderiam influenciar positivamente na hipertrofia de RGN, explorando ao máximo o potencial genético de animais DM. Já que o tipo de alimentação fornecido aos animais nessas fases é de ampla influência na composição muscular, assim como na porcentagem de gordura do músculo (FELÍCIO, 1997). 
Tabela 6: Quantidade de lipídios totais, colágeno e fibras na carne de bovinos Nelore e Rubia Gallega x Nelore confinados

\begin{tabular}{|c|c|c|c|c|}
\hline Característica & $\mathrm{N}^{1}$ & $\mathrm{RGN}^{1}$ & $\mathrm{EPM}^{2}$ & $P$ \\
\hline Lipídios totais (\%) & 2,03 & 1,43 & 0,649 & 0,0489 \\
\hline Marmorização ${ }^{3}$ & 4,67 & 4,45 & 0,205 & 0,1605 \\
\hline Colágeno solúvel (\%) & 12,15 & 13,29 & 2,786 & 0,3090 \\
\hline Colágeno insolúvel (\%) & 87,85 & 86,71 & 2,786 & 0,3090 \\
\hline Colágeno total $(\mathrm{mg} / \mathrm{g})$ & 3,56 & 3,81 & 0,414 & 0,6727 \\
\hline Número fibra total ${ }^{4}$ & 105,75 & 110,25 & 5,429 & 0,5671 \\
\hline Número SO & 21,37 & 25,50 & 1,856 & 0,1384 \\
\hline Número FOG & 31,62 & 29,75 & 3,159 & 0,6810 \\
\hline Número FG & 52,75 & 55,00 & 3,507 & 0,6570 \\
\hline Diâmetro fibra total $(\mu \mathrm{m})^{3}$ & 105,75 & 110,25 & 5,429 & 0,5671 \\
\hline Diâmetro SO $(\mu \mathrm{m})$ & 21,37 & 25,50 & 1,856 & 0,1384 \\
\hline Diâmetro FOG ( $\mu \mathrm{m})$ & 31,62 & 29,75 & 3,159 & 0,6810 \\
\hline Diâmetro FG $(\mu \mathrm{m})$ & 52,75 & 55,00 & 3,507 & 0,6570 \\
\hline
\end{tabular}

${ }^{1} \mathrm{~N}$ : Nelore; RGN: cruzamento Rubia Gallega x Nelore.

${ }^{2}$ EPM: erro padrão da média.

${ }^{3}$ Prime (8-9,9); Choice (5-7,9); Select (4-4.9) e Standard (2-3,9).

${ }^{4} \mathrm{SO}$ : fibra oxidativa de contração lenta; FOG: fibra glicolítica-oxidativa de contração rápida; FG: fibra glicolítica de contração rápida.

Não foi observada diferença entre os grupos genéticos para aceitação geral, sabor, intensidade de sabor, maciez, intensidade de maciez, suculência e intensidade de suculência, na avaliação sensorial da carne ( $\mathrm{P}>$ 0,05; Tabela 7). Observou-se efeito do tempo de maturação em todas as características sensoriais avaliadas $(\mathrm{P}<0,05)$. Diferentes atributos sensoriais, determinam a aceitabilidade do produto pelo consumidor. Entre àqueles que influenciam a satisfação, destaca-se a maciez (CROUSE et al., 1989), o sabor e a suculência da carne cozida (JUDGE et al., 1989). Desses três fatores, a maciez desempenha o papel mais decisivo na compra pelo consumidor (KOOHMARAIE et al., 2002).

Os resultados obtidos para sabor e suculência da carne corroboram com Restle et al. (1995), que também não encontraram diferença na palatabilidade da carne de novilhos Charolês, Nelore e de seus cruzamentos. De acordo com Perobelli et al. (1994), carne com melhor palatabilidade pode ser atribuída à maior marmorização, ou às demais características sensoriais (WHEELER et al., 1996). Neste estudo, o escore de marmorização do músculo 
Longissimus thoracis, independente dos grupos genéticos, foi baixo, não influenciando o sabor da carne avaliada pelos consumidores. Por outro lado, Vaz et al. (2002) observaram carne mais palatável em novilhos Charolês que em novilhos Nelore.

Observou-se que maciez da carne, avaliada por meio do painel de consumidores, não foi similar a força de cisalhamento (FC). Portanto, a FC mostrou-se ser mais precisa em detectar diferenças entre amostras dos grupos genéticos avaliados. A textura é a primeira resposta do senso táctil ao estímulo físico, e o consumidor utiliza principalmente esse atributo para determinar a qualidade e a aceitabilidade da carne, mas é preciso uma diferença superior a 9,81N na FC para o provador perceber diferenças sensorias na textura (OUALI et al., 2013; PICARD et al., 2014). Além disso a qualidade sensorial da carne está altamente correlacionada ao teor e solubilidade do colágeno, a deposição de gordura e ao marmoreio (BONFATTI et al., 2013). Como os animais estudados apresentaram resultados próximos para estes fatores, e uma diferença na FC inferior a 9,8N sugere-se baixa influência dos grupos genéticos sobre o atributo de maciez sensorial.

Assim, de acordo com os resultados encontrados a maciez da carne em animais jovens não é influenciada pelo teor de colágeno e nem pelo número e diâmetro das fibras musculares, prevalecendo a influência de fatores genéticos da raça. 
Tabela 7: Atributos de avaliação sensorial da carne de bovinos Nelore e Rubia Gallega x Nelore confinados.

\begin{tabular}{|c|c|c|c|c|c|c|c|c|}
\hline \multicolumn{2}{|c|}{ Efeito fixo } & \multicolumn{7}{|c|}{ Característica $^{1}$} \\
\hline Tratamento $^{2}$ & Tempo $^{3}$ & $\mathbf{G}$ & $\mathbf{S}$ & SI & $\mathbf{M}$ & MI & SC & SCI \\
\hline \multicolumn{9}{|c|}{ Efeito principal } \\
\hline $\mathrm{N}$ & & 6,55 & 6,34 & 3,61 & 6,40 & 3,64 & 6,34 & 3,61 \\
\hline \multirow[t]{3}{*}{$\mathrm{R}$} & & 6,46 & 6,24 & 3,54 & 6,45 & 3,66 & 6,24 & 3,54 \\
\hline & 0 & $6,11^{\mathrm{a}}$ & $5,93^{\mathrm{a}}$ & $3,42^{a}$ & $5,61^{\mathrm{a}}$ & $3,13^{\mathrm{a}}$ & $5,93^{\mathrm{a}}$ & $3,42^{\mathrm{a}}$ \\
\hline & 14 & $6,90^{\mathrm{b}}$ & $6,65^{b}$ & $3,73^{b}$ & $7,25^{b}$ & $4,16^{\mathrm{b}}$ & $6,65^{b}$ & $3,73^{b}$ \\
\hline \multicolumn{9}{|c|}{ Média } \\
\hline Média & & 6,50 & 6,27 & 3,57 & 6,42 & 3,65 & 6,29 & 3,57 \\
\hline Erro Padrão & & 0,114 & 0,114 & 0,060 & 0,122 & 0,062 & 0,115 & 0,060 \\
\hline \multicolumn{9}{|c|}{ Probabilidade estatística } \\
\hline Tratamento & & 0,4214 & 0,3736 & 0,2957 & 0,7692 & 0,7790 & 0,3736 & 0,2957 \\
\hline Tempo & & $<0,0001$ & $<0,0001$ & $<0,0001$ & $<0,0001$ & $<0,0001$ & $<0,0001$ & $<0,0001$ \\
\hline Trat*Tempo & & 0,9085 & 0,5616 & 0,5132 & 0,4536 & 0,4000 & 0,5616 & 0,5132 \\
\hline
\end{tabular}

${ }^{1}$ G: geral (1-9); S: sabor (1-9); SI: sabor intensidade (1-5); M: maciez (1-9); MI: maciez intensidade (1-5); SC: suculência (1-9); SCI: suculência intensidade (1-5),

${ }^{2}$ Tratamento: N: Nelore; RGN: cruzamento Rubia Gallega x Nelore,

${ }^{3}$ Dia zero e Dia 14: Período de maturação da carne em câmara de resfriamento a $4{ }^{\circ} \mathrm{C}$,

a, b: Médias na mesma coluna seguidas por letras diferentes indicam que houve diferença entre si $(P \leq 0,05)$,

\subsection{CONCLUSÃO}

Animais cruzados Rubia Gallega x Nelore apresentaram melhor desempenho produtivo e características de carcaça superiores. Portanto, a estratégia do cruzamento industrial entre Bos taurus continental (Rubia Gallega) e Bos indicus (Nelore) pode ser utilizada, a fim de potencializar a produtividade, proporcionando maior taxa de crescimento muscular e, consequentemente, maior rendimento de carcaça e de cortes.

Assim, a utilização deste cruzamento não influencia a qualidade da carne de animais jovens, apesar das diferenças em maciez e gordura, estas características não são perceptíveis pelo consumidor. Desta forma, a carne de ambos os grupos genéticos atendem nichos de mercado em que se busca carnes mais favoráveis à saúde. A maior maciez da carne de bovinos Nelore e cruzados Rubia Gallega x Nelore pode ser obtida após 14 dias de maturação, não sendo necessário maturar as carnes por períodos superiores. 


\section{AGRADECIMENTOS}

O presente trabalho foi realizado com apoio financeiro da Coordenação de Aperfeiçoamento de Pessoal de Nível Superior - Brasil (CAPES) - Código de Financiamento 001. Os agradecimentos se estendem também à Fundação de Amparo à Pesquisa do Estado de São Paulo (FAPESP- 2012/50788-0). 


\section{REFERÊNCIAS}

ALBERTÍ, P.; RIPOLL, G.; GOYACHE, F.; LAHOZ, F.; OLLETA, J. L.; PANEA, B.; et al. Carcass characterization of seven Spanish beef breeds slaughtered at two commercial weights. Meat Science, v. 71, p. 514-521, 2005.

ALDAI, N.; NÁJERA, A. I.; DUGAN, M. E. R.; CELAYA, R.; OSORO, K. Characterization of intramuscular, intermuscular and subcutaneous adipose tissues in yearling bulls of different genetic groups. Meat Science, v. 76, p. 682-691, 2007.

AMERICAN MEAT SCIENCE ASSOCIATION (AMSA). Research guidelines for cookery, sensory evaluation and instrumental tenderness measurements of fresh meat. Chicago, IL: National Livestock and Meat Board. p. 48, 1995.

ARTHUR, P. F. Double muscling in cattle: a review. Australian Journal of Agricultural Research, v. 46, n.8, p.1493-1515. 1995.

BAILEY,A. J. The role of collagen in the development of muscle and relationship to eating quality. Journal of Animal Science. v.60. n.6, p.1580-1587, 1985.

BELEW, J. B.; BROOKS, J. C.; MCKENNA, D. R. et al. Warner-Bratzler shear evaluations of 40 bovine muscles. Meat Science, v.64, n.4, p.507-512, 2003.

BISPO E.; MONSERRAT L.; GONZÁLEZ L.; FRANCO D.; MORENO T. Effect of weaning status on animal performance and meat quality of Rubia Gallega calves. Meat Science v. 86, p. 832- 838, 2010.

BOCCARD, R. Relationship between muscle hypertrophy and the composition of skeletal muscle. Curr. Top. Vet. Med. Animal Science, v. 16, p. 148, 1982.

BONFATTI, V.; ALBERA, A.; CAMIER, P. Genetic associations between daily BW gain and live fleshiness of station-tested young bulls and carcass and meat quality traits of commercial intact males in Piemontese cattle. Journal of Animal Science, v. 91, p. 20572066, 2013.

BRANDSTETTER, A. The influence of castration and compensatory growth rate on metabolic and contractile muscle characteristics of growing bovine. Dissertation, Osterreichischer Kunst- und Kulturverlag, Wien, Austria, 1996.

BRASIL. Ministério da agricultura, Pecuária e Abastecimento. Regulamento de Inspeção Industrial e Sanitária de Produtos de Origem Animal (RIISPOA). Brasília, DF, 2017.

BREA, T.; GARCÍA, J.; MONSERRAT, L; SÁNCHEZ, L.; CARBALlO, J. A. Modelización, crecimiento y rendimiento potencial de machos y hembras de raza Rubia Gallega. Memoria CIAM 94-96. Xunta de Galicia: Consellería de Agricultura, Gandería e Política Agroalimentaria, p.313-329, 1998.

CHAMBAZ, A.; SCHEEDER, M. R. L.; KREUZER, M.; DUFEY, P. A. Meat quality of Angus, Simmental, Charolais and Limousin steers compared at the same Intramuscular fat contente. Meat Science, v. 63, p. 491- 500, 2003.

COLLE, M. J.; RICHARD, R. P.; KILLINGER, K. M.; BOHLSCHEID, J. C.; GRAY, A. 
R.; LOUCKS, W. I.; DAY, R. N.; COCHRAN, A. S.; NASADOS, J. A.; DOUMIT, M. E. Influence of extended aging on beef quality characteristics and sensory perception of steaks from the glueus medius and longissimus lumborum. Meat Science, v. 110, p. 32-29, 2015.

CROSS, H. R.; CARPENTER, Z. L.; SMITH, G. C. Effects of intramuscular collagen and elastin on bovine muscle tenderness. Journal of Food Science, v.38, n.6, p.998-1003, 1973.

CROUSE, J. D.; CUNDIFF, L. V.; KOCH, R. M.; KOOHMARAIRE, M.; SEIDEMAN, S. C. Comparison of Bos índicus and Bos taurus inheritance for carcass beef characteristic and mean palalatality. Journal of Animal Science, v. 67, p. 2661-2668, 1989.

CRUZ, G. M.; TUlliO, R. R.; ESTEVES, S. N.; ALENCAR, M. M.; CORDEIRO, C. A. Peso de abate de machos não castrados oara produção do bovino jovem. 2. Peso, idade e características de carcaça. Revista Brasileira de Zootecnia, v.33, n.3, p.646-657, 2004.

DE SMET, S.; RAES, K.; DEMEYER, D. Meat fatty acid composition as affected by fatness and genetic factors: a review. Animal Research, v. 53, p. 81-98, 2004.

DUBOWITZ, V.; BROOKE, M. Muscle biopsy: a modern approach. London: W. B. Saunders Company, p. 472, 1984.

EILERS, J. D.; TATUM, J. D.; MORGAN, J. B.; SMITH, G. C. Modification of early postmortem muscle $\mathrm{pH}$ and use of postmortem ageing to improve beef tenderness. Journal Animal Science, v. 74, p. 790-798, 1996.

EUCLIDES FILHO, K.; EUCLIDES, V.P.B.; FIGUEIREDO, G.R. et al. Avaliação de animais Nelore e seus mestiços com Charolês, Fleckvieh e Chianina, em três dietas. 1. Ganho de peso e conversão alimentar. Revista Brasileira de Zootecnia, v. 26, n. 1, p. 66-72. 1997.

EUCLIDES FILHO, K.; FIGUEIREDO, G.R. Retrospectiva e perspectivas de cruzamentos no Brasil. In: Simpósio Brasileiro sobre cruzamento industrial. Anais... Londrina: IAPAR, 2003, p.11-35.

FERGUSON, D. M. WARNER, R. D. Have we underestimated the impact of pre-slaughter stress on meat quality in ruminants? Meat Science, vol. 80, p. 12-19, 2008.

FEITOSA, F. L. B.; OLIVIERI, B. F.; ABOUJAOUDE, C. et al. Genetic correlation estimates between beef fatty acid profile with meat and carcass traits in Nellore cattle finished in feedlot. Journal of Applied Genetics, v. 58, p. 123-132, 2017.

FELÍCIO, P. E. Fatores ante e post mortem que influenciam na qualidade da carne bovina. In: SIMPÓSIO SOBRE A PECUÁRIA DE CORTE: PRODUÇÃO DO NOVILHO DE CORTE, 1997. Piracicaba. Anais...Piracicaba: FEALQ, 1997. p. 79-97.

FERREIRA, V. L. P. Análise sensorial: testes discriminativos e afetivos. Campinas, SP.: SBCTA, 2000. 127 p.

FIEMS, L. O. Double muscling in cattle: genes, husbandry, carcasses and meat. Animals, v. 2, p. 472-506, 2012.

FOX, D. G.; TEDESCHI, L. O.; TYLUTKI, T. P.; RUSSELL, J. B., VAN AMBURGH, M. E., CHASE, L. E., PELL, A. N., OVERTON, T. R. The Cornell Net Carbohydrate and 
Protein System model for evaluating herd nutrition and nutrient excretion. Animal Feed Science and Technology, v. 112, n. 1/4, p. 29-78, 2004.

GAGNIÈRE, H.; PICARD, B.; JURIE, C.; GEAY, Y. Comparative study of metabolic differentiation of fetal muscle in normal and doublemuscled cattle. Meat Science. v. 45, n.2, p. 145-152, 1997.

GONZÁLEZ, A.; AALHUS, J. L. Exploring innovative possibilities of recovering the value of dark-cutting beef in the Canadian grading system. Meat Science, v. 137, p. 77-84, 2018.

HAWKINS, R. R.; MOODY, W. G.; KEMP, J. D. Influence of genetic type, slaughter weight and sex on ovine muscle fiber and fat cell development. Journal of Animal Science, Champaign, v. 61, n. 5, p. 1154-1163, 1985.

HEINEMANN, R. J. B.; PINTO M. F.; ROMANELLI, P. F. Fatores que influenciam a textura da carne de novilhos Nelore e cruzados Limousin-Nelore. Pesquisa Agropecuária Brasileira, v.38, p.963-971, 2003.

HONIKEL, K. O. Reference methods for the assessment of physical characteristics of meat. Meat Science, Amsterdam, v. 49, p. 447-457, 1998.

HOUBEN, J. H.; VAN DIJK, A.; EIKELENBOOM, G.; HOVING-BOLINK, A. H. Effect of dietary vitamin E supplementation, fat level and packaging on colour stability and lipid oxidation in minced beef. Meat Science, v. 55, p. 331-336, 2000.

JUDGE, M. D.; ABERLE, E. D.; FORREST, J. C.; HEDRICK, H. B.; MERKEL. R. A. Principles of meat science. 2 Ed. Kendall/Hunt Pub. Co. Dubuque, Iowa., p. 271, 1989.

KOOHMARAIE, M. Muscle proteinases and meat aging. Meat Science, v.36, n.1, p 93104, 1994.

KOOHMARAIE, M.; KENT, M.P.; SHACKEIFORD, S.D.; VEISETH, E.; WHEELER, T. L. Meat tenderness and muscle growth: is there any relationship? Meat Science, v. 62, p. 345-352, 2002.

KOOHMARAIE, M.; VEISETH, E., KENT, M. P.; SHACKELFORD, S. D. Understanding and managing variation in meat tenderness. In: REUNIÃO ANUAL DA SOCIEDADE BRASILEIRA DE ZOOTECNIA, 40., 2003, Santa Maria. Anais... Santa Maria: SBZ, 2003. p.513.

KOURY FILHO, W. Escores visuais e suas relações em características de crescimento em bovinos de corte. 2005. 80 f. Tese (Doutorado em Zootecnia e Produção Animal) Universidade Estadual Paulista, Jaboticabal, 2005.

LAWRENCE, T. E.; WHATLEY, J. D.; MONTGOMERY, T. H.; PERINO, L. J.; DIKEMAN, M. E. Influence of dental carcass maturity classification on carcass traits and tenderness of longissimus steaks from commercially fed cattle. Journal of Animal Science, v. 79, p. 2092-2096, 2001.

LINDAHL, G.; LUNDSTRÖM, K.; TORNBERG, E. Contribution of pigment content, myoglobin forms and internal reflectance to the colour of pork loin and ham from pure breed pigs. Meat Science, v. 59, p. 141-151, 2001. 
LOPES, M.; SAMPAIO, A. A. M. Manual do confinador de bovinos de corte. Minas Gerais: UFLA, p. 106, 1999.

LOPES, L. S.; LADEIRA, M..; MACHADO NETO, O. R.; PAULINO, P. V. R.; CHIZZOTTI, M. L.; RAMOS, E. M.; OLIVEIRA, D. M. Características de carcaça e cortes comerciais de tourinhos Red Norte e Nelore terminados em confinamento. Revista Brasileira de Zootecnia, v. 41, p. 970-977, 2012.

LUCHIARI FILHO, A. Pecuária da carne bovina. 1.ed. São Paulo: Albino Luchiari Filho, 134 p, 2000.

LYNCH G. S.; KOOPMAN, R. Overcoming nature's paradox in skeletal muscle to optimise animal production. Animal Production Science, v. 50, p. 11, 2019.

MARCONDES, M. I.; FILHO, S. C. V.; PAULINO, P. V. R.; DETMANN, E.; VALADARES, R. F. D.; SANTOS, T. R.; DINIZ, L. L. Predição da composição corporal e da carcaça a partir da seção entre a $9^{\mathrm{a}}$ e a $11^{\mathrm{a}}$ costelas em bovinos Nelore. Revista Brasileira de Zootecnia, v. 38, n.8, p. 1597-1604, 2009.

MARTINS, T.; SANGLARD, L.; SILVA, W.; CHIZZOTTI, M.; LADEIRA, M.; SERÃO, N.; PAULINO, P. V. R.; DUARTE, M. Differences in skeletal muscle proteolysis in Nellore and Angus cattle might be driven by Calpastatin activity and not the abundance of Calpain/Calpastatin. The Journal of Agricultural Science, v. 155, p. 1669-1676, 2017.

McPHERRON, A. C.; LEE, S. J. Double muscling in cattle due to mutations in the myostatin gene. Proceedings of the National Academy of Sciences of United States of America, v. 94, n.23, p. 12457-12461, 1997.

MENEZES, L. F. G.; RESTLE, J. Desempenho de novilhos de gerações avançadas do cruzamento alternado entre as raças Charolês e Nelore, terminados em confinamento. Revista Brasileira de Zootecnia, v. 34, p. 1927-1937, 2005.

MONSERRAT, L.; SÁNCHEZ, L. Sistemas de producción de carne en pastoreo con Rubia Gallega. Bovis, v. 92, p. 23-34, 2000.

MONSÓN, F.; SAÑUDO, C.; SIERRA, I. Influence of cattle breed and ageing time on textural meat quality. Meat Science, v. 68, p. 595-602, 2004.

MORALES, D.C.; CHARDULO, L. A. L.; SILVEIRA.A.C.; OLIVEIRA, H.N., ARRIGONI, M.B.; MARTINS, C.L.; CERVIERI, R.C. Características de qualidade de carne de bovinos de corte de diferentes tamanhos à maturidade submetidos ao sistema superprecoce. Acta Scientiarum, v. 24, n. 4, p. 1-2, 2002.

MORENO, T.; VARELA, A.; OLIETE, B.; CARBALlO, J.; SANCHEZ, L.; MONTSERRAT, L. Nutritional characteristics of veal from weaned and unweaned calves: Discriminatory ability of the fat profile. Meat Science, v. 73, p. 209-217, 2006.

MUCHENJE, V.; DZAMA, K.; CHIMONYO, M.; STRYDOM, P. E.; HUGO, A.; RAATS, J. G. Some biochemical aspects pertaining to beef eating quality and consumer health: A review. Food Chemistry, v. 112, n. 2, p. 279-289, 2009.

O'KEFFE, M.; HOOD, D. E. Biochemical factors influencing metamyoglobin formation in 
beef from muscles of differing colour stability. Meat Science, v. 7, p. 209, 1982.

OLIETE, B.; MORENO, T.; CARBALLO, J. A.; MONSERRAT, L.; SANCHEZ, L. Estúdio de lacalidad de la carne de ternera de raza Rubia Gallega a lo largo de la maduración al vacio. Archivos de Zootecnia, v. 55, p. 3-14, 2006.

OLIVEIRA, D. M.; LADEIRA, M. M.; CHIZZOTTI, M. L.; MACHADO NETO, O. R.; RAMOS, E. M.; GONÇALVES, T. M.; BASSI, M. S.; LANNA, D. P. D.; RIBEIRO, J. S. Fatty acid profile and qualitative characteristics of meat from zebu steers fed with different oilseeds. Jounal of Animal Science, v. 89, n.8, p. 2546-55, 2011.

OUALI, A.; GAGAOUA, M.; BOUDIDA, Y.; BECILA, S.; BOUDJELLAL, A.; HERRERA-MENDEZ, C. H.; SENTANDREU, M. A. Biomarkers of meat tenderness: present knowledge and perspectives in regards to our current understanding of the mechanisms involved. Meat Science, v. 95, n. 4, p. 854-870, 2013.

OZAWA, S.; MITSUHASHI, T.; MITSUMOTO, M.; MATSUMOTO, S.; ITOH, N.; ITAGAKI, K.; KOHNO, Y.; DOHGO, T. The characteristics of muscle fiber types of longissimus thoracis muscle and their influences on the quantity and quality of meat from Japanese Black steers. Meat Science, Champaign, v. 54, n. 1, p. 65-70, 2000.

PALHARI C. Desempenho e Qualidade de Carcaça de Garrotes Nelore e F1 Rubia Galega x Nelore Suplementados com Cromo Picolinato. 2014. 50 f. Dissertação (Mestrado) - Universidade Federal do Mato Grosso, Mato Grosso, 2014.

PATEIRO, M.; GENDE, A.; BERMÚDEZ, R.; GONZÁLEZ, J.; LORENZO, J. M.; FRANCO, D. Effect of crossing with Rubia Gallega and Limousine on meat quality of Friesian calves. 63rd International Congress of Meat Science and Technology, 2017.

PEREIRA, J. C. C. Melhoramento genético aplicado a produção animal. $4^{\mathrm{a}}$ Ed. Belo Horizonte: FEPMVZ, 2012.

PEROBELLI, Z. V.; RESTLE, J.; MÜLLER, L. Estudo das carcaças de vacas de descarte das raças Charolês e Nelore. Pesquisa Agropecuária Brasileira, v. 30, n. 3, p. 409-412, 1995.

PETER, J. B.; BARNARD, R. J.; EDGERTON, V. R. GILLESPIE, C. A., STEMPEL, K. E. Metabolic profiles of three fiber types of skeletal muscle in Guinea pig and rabbits. Biochemistry, v.11, p. 2627-2633, 1972.

PEARSE, A. G. E. Histochemistry, theoretical and applied. 3rd ed. Edimburgo: Churchill \& Livingstone, 1972.

PHOCAS, F. Genetic analysis of breeding traits in a Charolais cattle population segregating an inactive myostatin allele. Journal of Animal Science, v. 87, n. 6, p. 1865-1871, 2009.

PICARD, B.; GAGAOUA, M.; MICOL, D.; CASSAR-MALEK, I.; HOCQUETTE, J. F.; TERLOUW, C. E. Inverse relationships between biomarkers and beef tenderness according to contractile and metabolic properties of the muscle. Journal of Agricultural and Food Chemistry, v. 62, p. 9808-9818, 2014.

PRIETO, N.; LÓPEZ-CAMPOS, Ó.; SUMAN, S. P.; UTTARO, B.; RODAS-SALVIANO- 
TEIXEIRA, C.; OLIVEIRA, D. A. A.; QUIRINO, C. R. Musculatura dupla. I Características de desempenho e da carcaça de bovinos. Archivo Latinoamericano de Produccion Animal, v. 14, p. 10-16, 2006.

PUGA, D. M. U.; CONTRERAS, C. J. C.; TURNBULL, M. R. Avaliação do amaciamento da carne bovina de dianteiro (Triceps brachi) pelos métodos de maturação, estimulação elétrica, injeção de ácidos e tenderização mecânica. Ciência e Tecnologia de Alimentos, Campinas, v. 19, n. 1, p. 88-96, 1999.

RESTLE, J.; FELTEN, H. G.; VAZ, F. N. Efeito de raça e heterose para características quantitativas da carcaça de novilhos de 24 meses de idade terminados em confinamento. In: REUNIÓN LATINOAMERICANA DE PRODUCCIÓN ANIMAL, 14, 1997. Mar del Plata. Memorias... Balcarce: ALPA, 1995. p.857-859.

RESTlE, J.; ALVES FILHO, D. C.; FATURI, C.; ROSA, J. R. P.; PASCOAL, L. L.; BERNARDES, R. A. C.; KUSS, F. Desempenho na fase de crescimento de machos bovinos inteiros ou castrados de diferentes grupos genéticos. Revista Brasileira de Zootecnia, Viçosa: v.29, n.4, p.1036-1043, 2000.

RUBENSAM, J. M.; FELÍCIO, P. E.; TERMIGNONI, C. Influência do genótipo Bos indicus na atividade de calpastatina e na textura da carne de novilhos abatidos no sul do Brasil. Ciência e Tecnologia de Alimentos, Campinas, v. 18, n. 4, p. 405-409, 1998.

REHFELDT, C.; FIEDLER, I.; STICKLAND, N.C. Number and Size of Muscle Fiber in Relation to Meat Production. In: TE PAS, M.F.W.; EVERTS, M.E.; HAAGSMAN, H.P. Muscle Development of Livestock Production: Physiology, Genetics and Meat Quality. 1. ed. Oxfordshire: Cabi Publishing, p.1-38, 2004.

SAINZ, R. D.; HASTING, E. Simulation of the development of adipose tissue in beef cattle. In: MCNAMARA, J. P.; FRANCE, J.; BEEVER, D. E.(Ed). Modeling nutrient utilization in farm animals. New York: CABI, 2000. p.175-182.

SÁNCHEZ L.; CARBALLO J.A.; SÁNCHEZ B.; MONSERRAT L. 2005a. Características de la canal y de la carne de machos Procedentes del cruce de Rubia Gallega con Nelore. Archivos de Zootecnia, v. 54, n. 206-207, p. 485-489, 2005 a.

SÁNCHEZ, L; BECERRA, J. J.; IGLESIAS, A.; MONSERRAT, L. Valoración del crecimiento en animals cruzados de Rubia Gallega con Nelore. Archivos de Zootecnia, v. 54, n. 206-207, p. 498, 2005 b.

SAÑUDO C.; SIERRA I.; OLLETA J. L.; MARTIN L.; CAMPO M. M.; SANTOLARIA P.; et al. Influence of weaning on carcass quality, fatty acid composition and meat quality in intensive lamb production system. Animal Science, v. 66, p. 175- 187, 1998.

SAÑUDO, C.; ENSER, M. E.; CAMPO, M. M.; NUTE, G. R.; MARÍA, G.; SIERRA, I.; WOOD, J. D. Fatty acid composition and sensory characteristics of lamb carcasses from Britain and Spain. Meat Science, v. 54, n. 4, p. 339-346, 2000.

SAZILI, A. Q.; LEE, G. K.; PARR, T.; SENSKY, P. L.; BARDSLEY, R. G.; BUTTERY, P. J. The effect of altered growth rates on the calpain proteolytic system and meat tenderness in cattle. Meat science, v. 66, p. 195-201, 2004. 
SCOLLAN, N.; HOCQUETTE, J.F.; NUERNBERG, K.; DANNENBERGER, D.; RICHARDSON, I.; MOLONEY, A. Innovations in beef production systems that enhance the nutritional and health value of beef lipids and their relationship with meat quality. Meat Science, v. 74, p. 17- 33, 2006.

SILVA, M. J. F. B. Rendimento da carcaça e características físicas da carne de animais cruzados entre as raças Rubia Gallega e Nelore. 2011. 47f. Dissertação (Mestrado em Zootecnia) - Universidade Federal Rural de Pernambuco, Departamento de Zootecnia, Recife, 2011.

SHACKELFORD, S. D.; KOOHMARAIE, M.; CUNDIFF, L. V. et al. Heritabilities and phenotypic and genetic correlations for bovine post rigor calapstatin activity. intramuscular fat content. Warner-Bratzler shear force. retail product yield and growth rate. Journal of Animal Science, v.72, n.4, p.857-863, 1994.

SMITH J. A.; LEWIS, A. M.; WIENER, P.; WILLIAMS, J. L. Genetic variation in the bovine myostatin gene in UK beef cattle: allele frequencies and haplotype analysis in the South Devon. Animal Genetics, v. 31, n. 5, p. 306-309, 2000.

STANIŠIĆ, N.; PETRIČEVIĆ, M.; ŽIVKOVIĆ, D.; PETROVIĆ, M. M.; OSTOJIĆANDRIĆ, D.; ALEKSIĆ, S.; STAJIĆ, S. Changes of physical-chemical properties of beef during 14 days of chilling. Biotechnology in Animal Husbandry, v. 28, n. 1, p. 77 $85,2012$.

SUGUISAWA, L; MATTOS, W. R. S.; OLIVEIRA, H. N.; SILVEIRA, A. C.; ARRIGONI, M. B.; SOUZA, A. A. Correlação simples entre as medidas de ultra-som e a composição da carcaça de bovinos jovens. Revista Brasileira de Zootecnia. v. 35, n. 1, p. 169-176, 2006.

TAVEIRA, R. Z.; SILVEIRA NETO, O. J.; AMARAL, A.G.; LUZ, T. N; BRITO JÚNIOR, V. A. Comparação de desempenho de bovinos Nelore e mestiços Nelore-Rubia Gallega em sistema de confinamento. PUBVET, v. 8, p. 243-255, 2014.

UNITED STATES DEPARTAMENT OF AGRICULTURE (USDA). Standard specification for tenderness marketing claims associated with meat cuts derived from beef, 2011.

USDA. Official United States standards for grades of carcass beef. Agric. Marketting Serv., USDA, Washington, D.C., 1999.

USDA, National Agricultural Statistics Service (2019). Agricultural Statistics Board, by the National Agricultural Statistics Service (NASS).

UYTTERHAEGEN, L., CLAEYS, E.; DEMEYER, D.; LIPPENS, M.; FIEMS, L.O.; BOUCQUE, C.Y.; VANDERVOORDE, G.; BASTIAENS, A. Effects of double-muscling on carcass quality, beef tenderness and myofibrillar protein degradation in Belgian Blue and White bulls. Meat Science, v. 38, n. 2, p. 255-267, 1994.

VAZ, F. N.; RESTLE, J.; VAZ, R. Z.; BRONDANI, I. L.; BERNARDES, R. A. C. B.; FATURI, C. Efeitos de raça e heterose na composição física da carcaça e na qualidade da carne de novilhos da primeira geração de cruzamento entre Charolês e Nelore. Revista Brasileira de Zootecnia, v.21, n.1, p.376-386, 2002. 
WEGNER, J.; ALBRECHT, E.; ENDER, K. Morphological aspects of subcutaneous and intramuscular adipocyte growth in cattle. Arch. Tierz. Dummerstorf, v. 41, p. 313-320, 1998.

WEGNER, J.; ALBRECHT, E.; FIEDLER, I.; TEUSCHER, F.; PAPSTEIN, H. J.; ENDER, $\mathrm{K}$. Growth- and breed-related changes of muscle fiber characteristics in cattle. Journal of Animal Science, v. 78, n. 6, p. 1485-1496, 2000.

WHEELER, L.V.; CUNDIFF, R.M.; KOCH, J. D. Crouse Characterization of biological types of cattle (cycle IV): carcass traits and longissimus palatability. Journal of Animal Science, v. 74, p. 1023-1035, 1996.

WHEELER, T. L.; SHACKELFORD, S. D.; KOOHMARAIE, M. Tenderness classification of beef: IV. Effect of USDA quality grade on the palatability of "tender" beef longissimus when cooked well done. Journal of Animal Science, Champaign, v. 77, p. 882-888, 1999.

WHEELER, T. L.; SHACKELFORD, S. D.; CASAS, E.; CUNDIFF, L. V; KOOHMARAIE, M. The effects od Piemontese inheritance and myostatin genotype on the palatability of longissimus thoracis, gluteus medius, semimembranous, and biceps femoris. Journal of Animal Science. v. 79, p. 30-69, 2001.

WHEELER, T. L.; SHACKELFORD, S. D.; KOOHMARAIE, M. Shear force procedures for meat tenderness measurement. Roman L. Hruska U. S. Marc. USDA, Clay Center, NE, 2001.

WHEELER, T. L.; CUNDIFF, L. V.; HACKELFORD, S. D.; KOOHMARAIE, M. Characterization of biological types of cattle (Cycle VII): Carcass, yield, and longissimus palatability traits. Journal of Animal Science, v. 83, n. 1, p. 196-207, 2005.

WHEELER, T. L.; PAPADOPOULOS, L. S.; MILLER, R. K. Reserach Guidelines for Cookery, Sensory Evaluation, and Instrumental Tenderness Measurements of Meat. 2 Ed. Champaign, Illinois: American Meat Science Association, p. 104 , 2015.

WIENER, P.; WOOLLIAMS, J. A.; FRANK-LAWALE, A.; RYAN, M.; RICHARDSON, R. I.; NUTE, G. R.; WOOD, J. D.; HOMER, D.; WILLIAMS, J. L. The effects of a mutation in the myostatin gene on meat and carcass quality. Meat Science, v. 83, p. 127-134, 2009.

WILSON, D. E.; ROUSE, G. H.; GREINER, S. Relationship between chemical percentage intramuscular fat and USDA marbling score. Beef Research Report. AS Leaflet 1529. Iowa State University, Iowa Beef Center, 1998.

XAVIER, S. R. Prospecção de Polimorfismo no Gene da Miostatina em Bovinos da Raça Senepol. 2014. Dissertação (Mestrado em Zootecnia). Universidade Federal do Mato Grosso do Sul, 2014.

YÜKSEI, S.; YANAR, M.; AKSU, M. I.; KOPUZLU, S.; KABAN, G. SEZGIN, E.; OZ, F. Effects os different finishing systems on carcass traits, fatty acid composition, and beef quality characteristics of young Eastern Anatolian Red bulls. Tropical Animal Health and Production, v.44, p. 1521-1528, 2012.

ZORZI, K; BONILHA, S. F. M.; QUEIROZ, A. C.; BRANCO, R. H.; SOBRINHO, T. L.; DUARTE, M. S. Meat quality of young Nellore bulls with low and high residual feed intake. Meat Science, v. 93, p. 593-599, 2013. 
ANEXO A
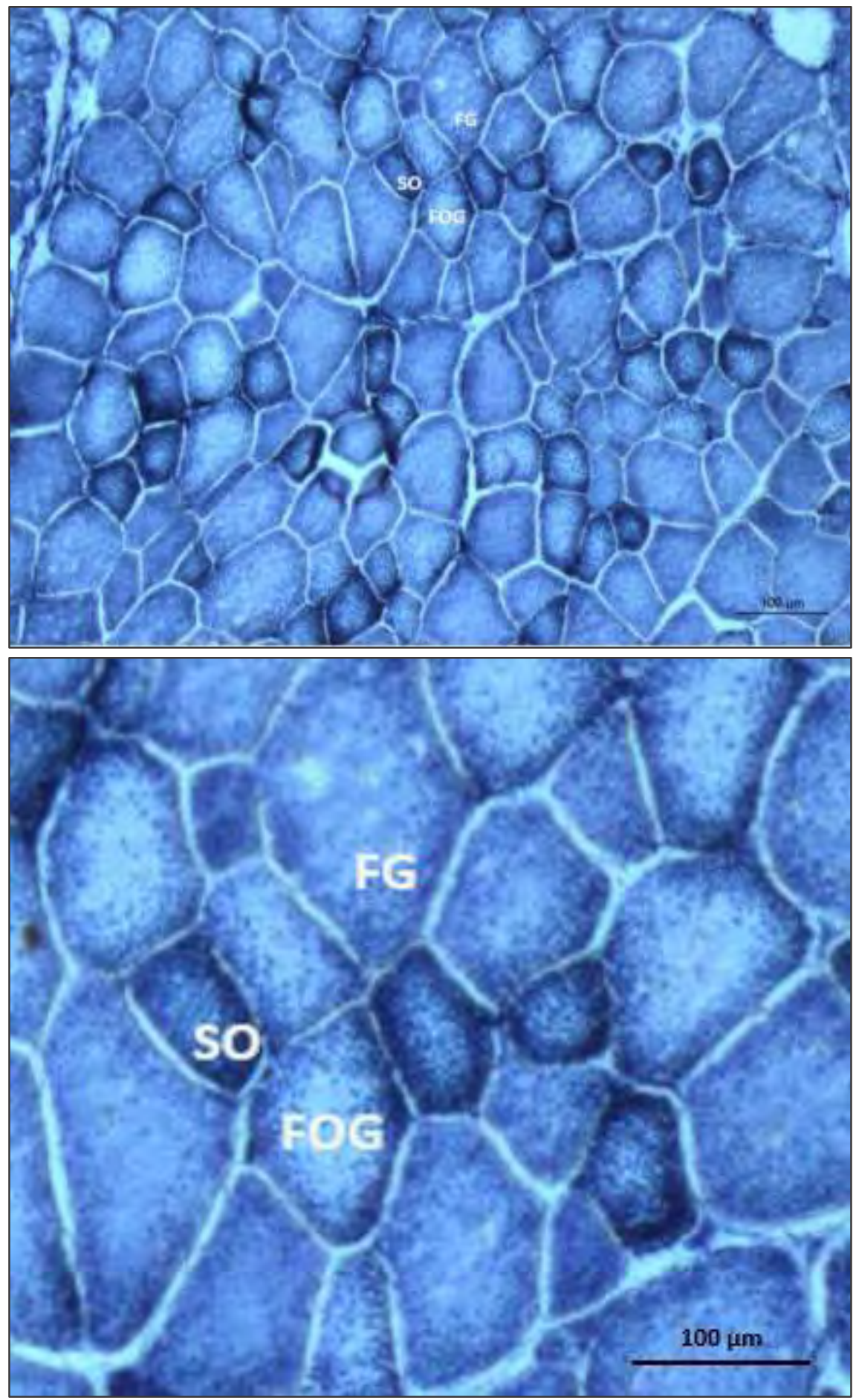

Figura 3. Fotomicrografia de seção transversal do músculo Longissimus thoracis tingido histoquimicamente pela técnica da NADH-TR diaforase. Sítios com coloração escura indicam atividade enzimática intensa, representando fibras oxidativas SO (tipos I). A falta de coloração indica baixa concentração de mitocôndrias, representando as fibras glicolíticas FG (tipo IIx). Sítios de coloração intermediária representam fibras glicolíticas-oxidativas FOG (tipo IIa). 
Nome:

Amostra:

Provador:

Antes de provar a amostra, por favor coma um pedaço da bolacha e tome um gole de água.

PROVE A AMOSTRA - Obs: marque as respostas com um $X$ dentro do balão referente à sua opinião.

1. De um modo GERAL de satisfação, o quanto você gostou ou desgostou da amostra?

$\begin{array}{ccccccc}\text { Detestei } & \begin{array}{c}\text { Desgostei } \\ \text { muito }\end{array} & \begin{array}{c}\text { Desgostei } \\ \text { moderado }\end{array} & \begin{array}{c}\text { Desgostei } \\ \text { ligeiramente }\end{array} & \begin{array}{c}\text { Nem gostei } \\ \text { Nem desgostei }\end{array} & \begin{array}{c}\text { Gostei } \\ \text { ligeiramente } \\ \text { moderado }\end{array} & \end{array}$

2. O quanto você gostou ou desgostou do SABOR da amostra?

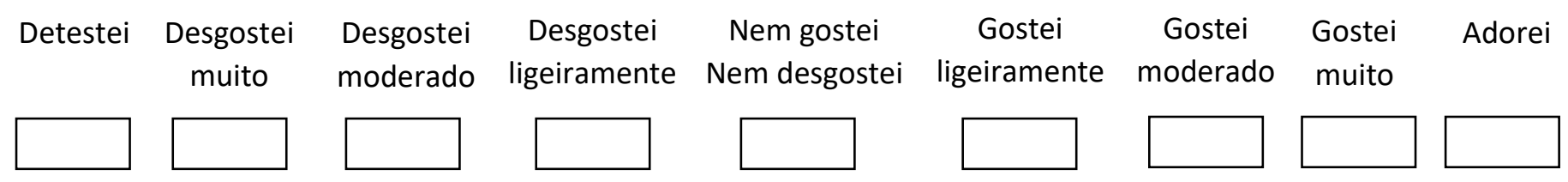

3. Você diria que o SABOR da amostra é:

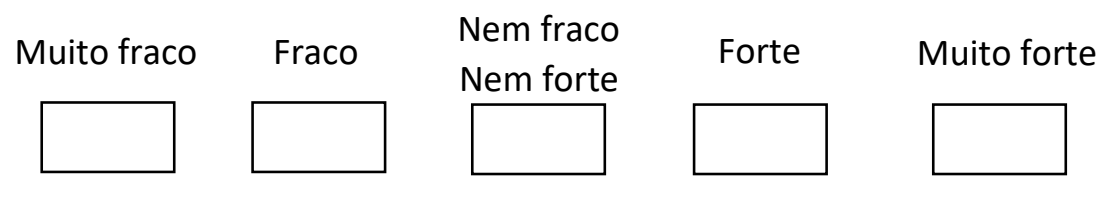

4. O quanto você gostou ou desgostou da MACIEZ da amostra?

\begin{tabular}{ccccccc} 
Detestei & $\begin{array}{c}\text { Desgostei } \\
\text { muito }\end{array}$ & $\begin{array}{c}\text { Desgostei } \\
\text { moderado }\end{array}$ & $\begin{array}{c}\text { Desgostei } \\
\text { ligeiramente }\end{array}$ & $\begin{array}{c}\text { Nem gostei } \\
\text { Nem desgostei }\end{array}$ & $\begin{array}{c}\text { Gostei } \\
\text { ligeiramente } \\
\text { moderado }\end{array}$ & $\begin{array}{c}\text { Gostei } \\
\text { muito }\end{array}$ \\
\hline
\end{tabular}

5. Você diria que, com relação à MACIEZ, a amostra é:

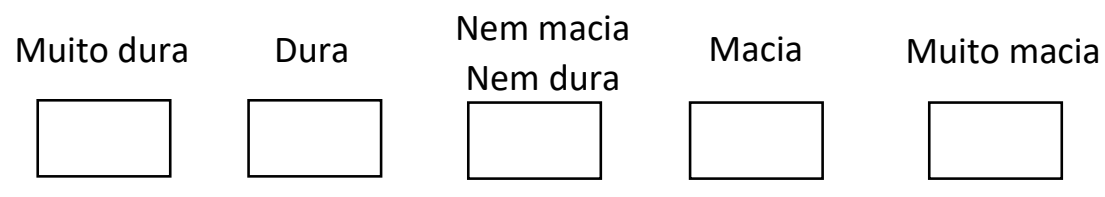

6. O quanto você gostou ou desgostou da SUCULÊNCIA da amostra?

\begin{tabular}{ccccccc} 
Detestei & $\begin{array}{c}\text { Desgostei } \\
\text { muito }\end{array}$ & $\begin{array}{c}\text { Desgostei } \\
\text { moderado }\end{array}$ & $\begin{array}{c}\text { Desgostei } \\
\text { ligeiramente }\end{array}$ & $\begin{array}{c}\text { Nem gostei } \\
\text { Nem desgostei }\end{array}$ & $\begin{array}{c}\text { Gostei } \\
\text { ligeiramente }\end{array}$ \\
\hline
\end{tabular}

7. Você diria que a SUCULÊNCIA da amostra é:

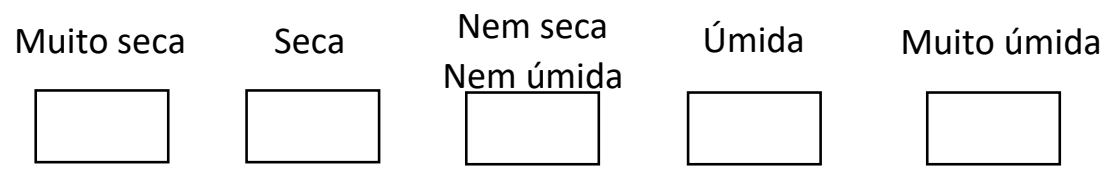

